$$
\text { TINAL MEPOQ2 }
$$

\title{
Direct Use of Geothermal Energy at the \\ San Bepnardino \\ Wastewater Treatment Plant
}

\section{Prepared for the \\ California Energy Commission Agreement 500-81-005}

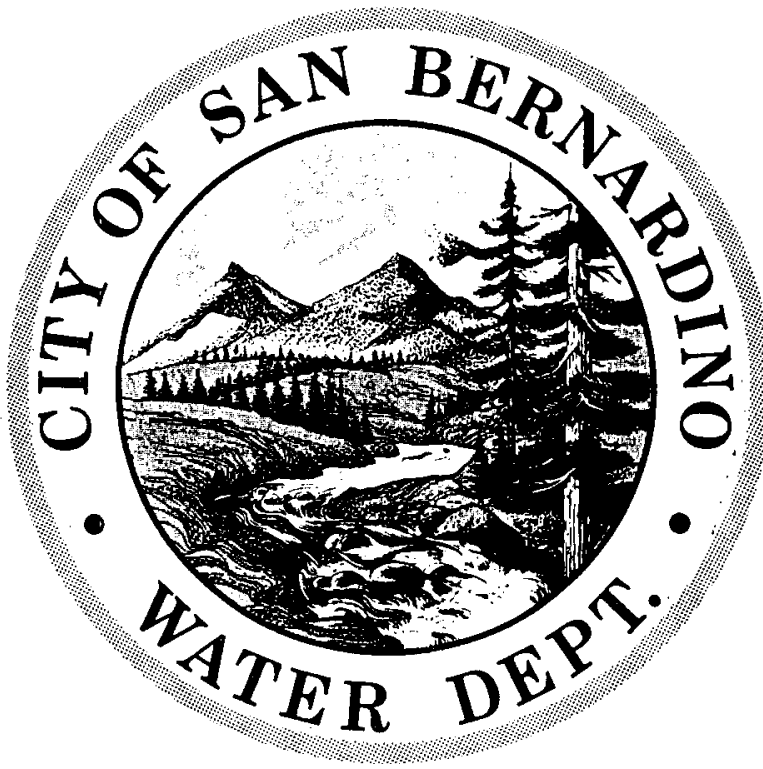

SAN BERNARDINO MUNICIPAL WATER DEPARTMENT

Board of Water Commissioners

Margaret Chandler, President

Harold Willis

Robert Bivens

Emilia Garcia

James Urata

General Manager 


\section{DISCLAIMER}

This report was prepared as an account of work sponsored by an agency of the United States Government. Neither the United States Government nor any agency Thereof, nor any of their employees, makes any warranty, express or implied, or assumes any legal liability or responsibility for the accuracy, completeness, or usefulness of any information, apparatus, product, or process disclosed, or represents that its use would not infringe privately owned rights. Reference herein to any specific commercial product, process, or service by trade name, trademark, manufacturer, or otherwise does not necessarily constitute or imply its endorsement, recommendation, or favoring by the United States Government or any agency thereof. The views and opinions of authors expressed herein do not necessarily state or reflect those of the United States Government or any agency thereof. 


\section{DISCLAIMER}

Portions of this document may be illegible in electronic image products. Images are produced from the best available original document. 


\section{ABSTRACT}

This report provides a chronological and technical evaluation of the successful use of geothermal energy in San Bernardino, California to provide heating for wastewater treatment facilities.

The annual cost savings for the currently tested system is more than $\$ 29,425$ for the single anaerobic digester now being heated. Expansion of the wastewater facility, resulting in two additional digesters, could result in three geothermal heated digesters on line--a minimum of two. This expanded usage, together with expected natural gas price increases, should result in recovery of all investment costs in less than ten years. 


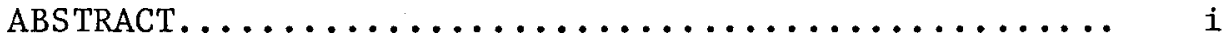

TABLE OF CONTENTS $\ldots \ldots \ldots \ldots \ldots \ldots \ldots \ldots \ldots \ldots \ldots \ldots \ldots \ldots \ldots$

LIST OF FIGURES $\ldots \ldots \ldots \ldots \ldots \ldots \ldots \ldots \ldots \ldots \ldots \ldots \ldots \ldots \ldots \ldots \ldots$

LIST OF TABLES $\ldots \ldots \ldots \ldots \ldots \ldots \ldots \ldots \ldots \ldots \ldots \ldots$ iv

APPENDIXES $\ldots \ldots \ldots \ldots \ldots \ldots \ldots \ldots \ldots \ldots \ldots \ldots \ldots \ldots \ldots \ldots \ldots \ldots \ldots$

1. INTRODUCTION $\ldots \ldots \ldots \ldots \ldots \ldots \ldots \ldots \ldots \ldots \ldots \ldots \ldots \ldots \ldots$

2. RESOURCE CONF IRMATION AND DEVELOPMENT $\ldots \ldots \ldots \ldots \ldots \ldots 2$

2.1 Recommendation for a Drilling Program ........ 2

2.2 Permits and Agreements .................... 6

2.3 Selection of Drilling Contractor ........... 7

2.4 Drilling, Logging, Completion of Thermal

Gradient Wells .................... 7

2.4.1 Stratigraphic Summary ............ 8

2.4.2 Geologic Structure and Distribution of Thermal waters.................. 8

2.4.3 Hydrology of Thermal Waters .......... 12

2.4.4 Recommendations for Production Well .... 13

3. ACQUISITION OF PRODUCTION WELL AND INSTALLATION

OF TRANSMISS ION LINES ........................ 14

3.1 Acquisition of Production well ........... 14

3.2 Rework of Meeks and Daley $\$ 66 \ldots \ldots \ldots \ldots \ldots \ldots . \ldots . \ldots 16$

3.3 Transmission Pipeline Installation .......... 20

4. SYSTEM DESIGN, TESTING, START-UP.............. 24

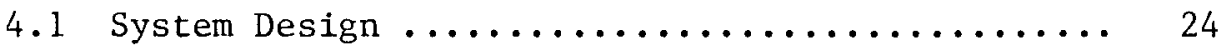

4.1 .1 Heat Exchanger ..................... 24

4.1.2 Pump and Motor-Meeks and Daley $\# 66 \ldots \ldots 28$

4.1.3 Disposal of Geothermal Fluid ......... 31

5. PROJECT COST SUMMARY AND CONCLUSIONS ........... 32

5.1 Projected Natural Gas Savings ............. 32

5.2 Cost Comparison of Geothermal Energy

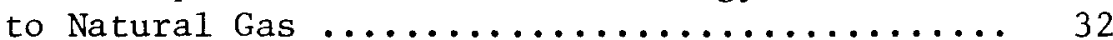

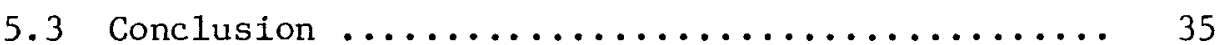




\section{LIST OF FIGURES}

$\underline{\text { PAGE }}$

1. Location Map San Bernardino Vicinity.............. 3

2. Proposed Cásing Program for 1500' Temperature Gradient/Observation Well................... 5

3. Structure Contour Map on Top of the San

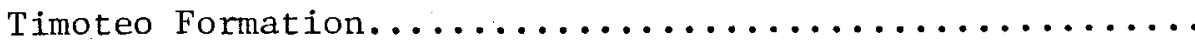

4. Maximum Temperature Contour Map................. 11

5. Proposed Geothermal Production Well Properties and Existing Meeks and Daley Well No. $66 \ldots \ldots \ldots \ldots \ldots$

6. Meeks and Daley We11 No. 66 Temperature

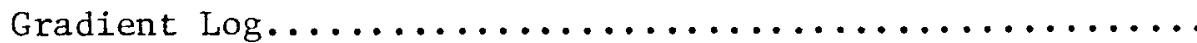

7. Pipeline Route From Meeks and Daley Well No. 66 to Digester Area of Wastewater Treat-

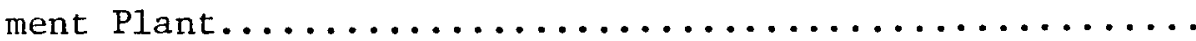

8. Piping and Instrumentation Diagram Geothermal

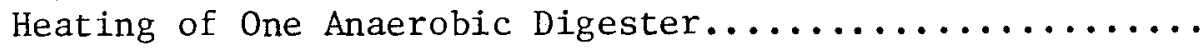




\section{LIST OF TABLES}

PAGE

1. Driller's Log From Meeks and Daley Well

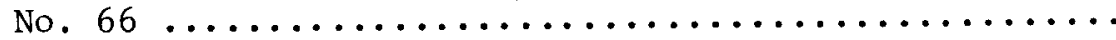

2. Thermal Survey Data From Meeks and Daley Well No. 66.

3. Temperature and Flow Test - Meeks and Daley Wel1 No. 66

4. Design Criteria For Determining Pipe

Diameter............................. 20

5. Key to Drawing Symbols................... 26

6. Analysis of Water Samples From Meeks and

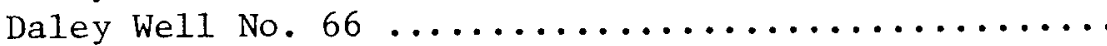

7. Flow Test on East Digester Heat Exchanger

Meeks and Daley Well No. 66 Flowing Artesian........

8. Flow Test on East Digester Heat Exchanger Meeks and Daley Well No. 66 Pumped

9. Summary of Project Costs for Direct Use of Geothermal Energy at the San Bernardino Wastewater Treatment Plant 


\section{APPENDIXES}

A.

Stratigraphic and Geologic Data - Temperature Gradient Wells

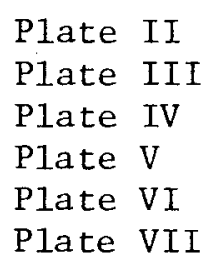

B. Data Concerning TG No. 1.

C. Data Concerning TG No. 2 .

D. Data Concerning TG No. 4A.

E. Data Concerning TG No. 5A.

F. Temperature Profiles

Meeks \& Daley \#66

TG No. 2 


\section{1 - INTRODUCTION}

In June, 1981, the San Bernardino Municipal Water Department completed a study funded by the Department of Energy entitled, "Feasibility Study For Wastewater Treatment Utilizing Geothermal Energy In San Bernardino". The study indicated that use of low temperature geothermal heat for heating primary anaerobic digesters was feasible.

Following completion of the feasibility study, an agreement was executed between the California Energy Commission and the Board of Water Commissioners, City of San Bernardino, to implement the project. The State agreed to fund $90 \%$ of the project costs up to a maximum of $\$ 390,600$. The project was segmented into the following components: (1) resource confirmation and development, including the drilling and logging of temperature gradient wells and the development/acquisition of a production well; (2) purchase and installation of transmission and distribution facilities; (3) retrofit of heat exchangers at the anaerobic digesters; and (4) system testing and implementation of direct use of geothermal heat for the digesters.

The project is complete and heating one primary anaerobic digester. There is capability and capacity in the production well and transmission facilities to heat two additional digesters. Annual offset of natural gas/methane to fuel a boiler to heat one digester by utilizing geothermal energy is 43,800 therms. When all three digesters are heated with geothermal energy, the total offset of natural gas/methane annual is 164,250 therms. The annual cost savings by utilizing geothermal energy to heat one digester at the current natural gas cost is $\$ 29,425$. 
2 - RESOURCE CONFIRMATION AND DEVELOPMENT

\subsection{Recommendation for a Drilling Program.}

The first phase of this project was to conduct additional studies and field investigations to further evaluate the geothermal resource of the area.

The California Division of Mines and Geology conducted a geothermal assessment study in the San Bernardino area to investigate the low temperature geothermal resource. The report issued as a result of their study entitled, "Resource Investigation of Low and Moderate Temperature Geothermal Areas in San Bernardino, California", identified three active designated geothermal areas as the most 1ikely sites for geothermal exploration and development. The South San Bernardino area identified in the report was chosen as the area for further investigation since it was close to the direct use application. The report further states that the next phase of assessing or developing the geothermal resources of San Bernardino should be an exploratory drilling program, or a deep monitoring well drilling program.

Republic Geotherma1, Inc. was selected to develop a plan for drilling thermal gradient/observation wells and a production well. The report was submitted in November, 1981 and then amended subsequent to a meeting with representatives of the California Division of Mines and Geology and California Energy Commission in December, 1981. The project area (Figure 1), identified as the South San Bernardino Geothermal area, is one in which there are several wells that produce waters whose temperatures range from $24^{\circ} \mathrm{C}$ to $56^{\circ} \mathrm{C}$. Most of these wells are located near the suspected trace of the Loma Linda fault; however, their precise relationship to the fault was not known. Meeks and Daley $\# 66$ Well is located within the project area. The well is a known hot water well with temperature recordings of $56^{\circ} \mathrm{C}$. It was decided to conduct the drilling of thermal gradient wells rather than drilling a production well immediately near the Meeks and Daley $\$$ 66 Well. A possibility existed of finding a resource hotter than that supplying Meeks and Daley 非6 We1l by exploring along the fault. The temperature gradient wells also provided lithologic and temperature 


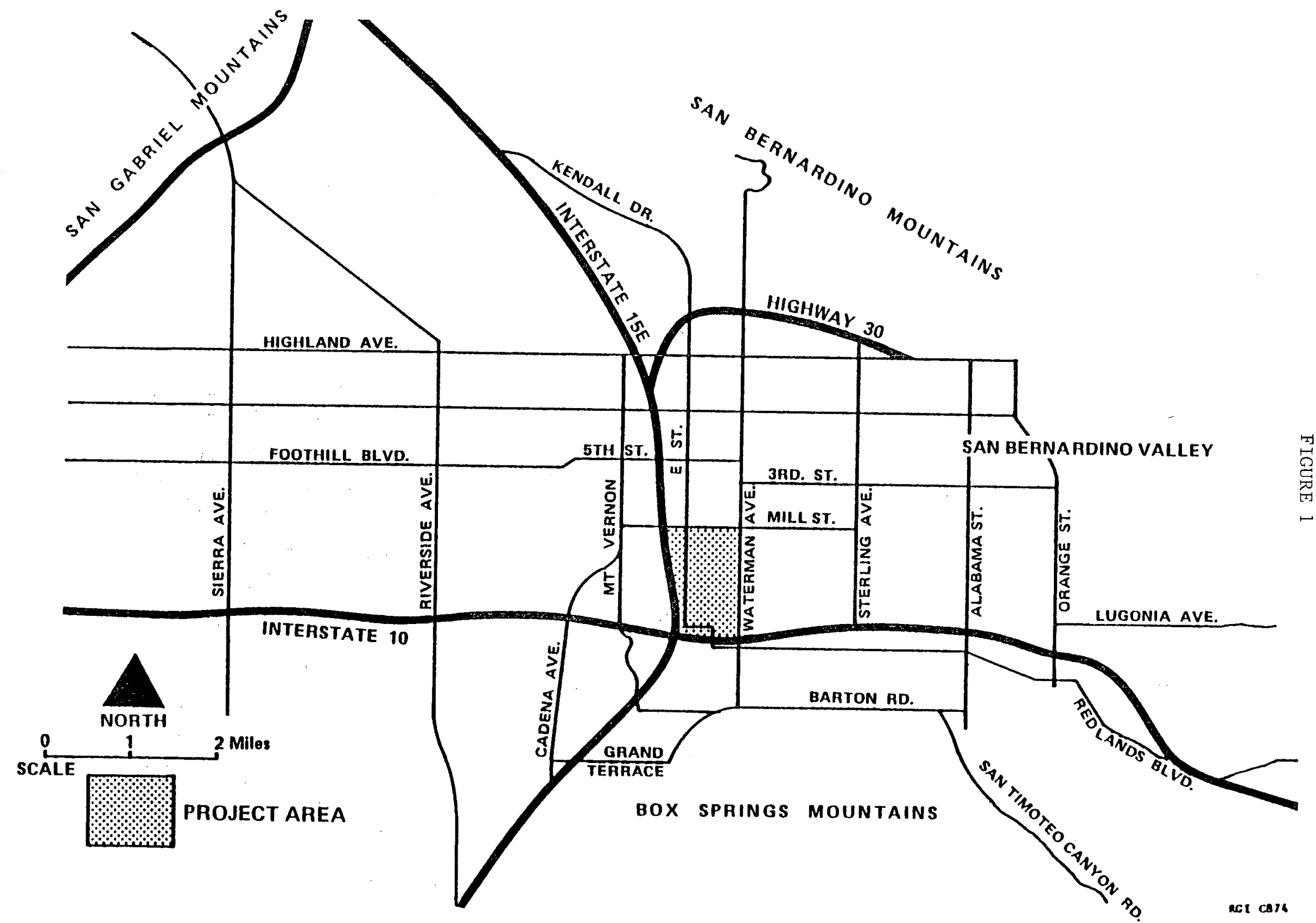

FIGURE 1

\author{
LOCATION MAP
}

SAN BERNARDINO VICINITY 
information needed to define the geothermal reservoir, and to design and locate future geothermal production wells.

The thermal gradient wells consist of a 2-7/8 inch diameter steel tube capped on the bottom, encased in cement, filled with water, and left undisturbed until the temperature of the water in the tube approaches equilibrium with temperature in adjacent sediments (Figure 2). The temperatures are measured to obtain the rate of increase of temperature with increasing depth, and to define a temperature profile which indicates zones of conductive and/or convective heat flow. The designed casing size will permit perforating tools into the well for later conversion into observation wells used for monitoring reservoir behavior. As part of the drilling program, self-potential, resistivity, gamma ray, and temperature logs for each thermal gradient well were conducted prior to cementing in the casing. This information, combined with drillers' logs, drill cutting analysis, and hydrologic data, provides for optimum design of production wells, and a greater understanding of the location of the geothermal resource.

Sites for the thermal gradient wells were recommended with the following logistical considerations in mind:

1. Distance from the wells to the wastewater treatment plant should be minimized while remaining consistent with the geological constraints.

2. Thermal gradient wells should be drilled predominantly on the west side of the San Bernardino County Flood Control District's canal to minimize the cost of crossing the canal with pipelines from a production well.

3. Thermal gradient well sites should be located on lands on which the San Bernardino Municipal Water Department has or can acquire the right to drill. 


\section{PROPOSED CASING PROGRAM FOR 1500' TEMPERATURE GRADIENT/OBSERVATION WELL}

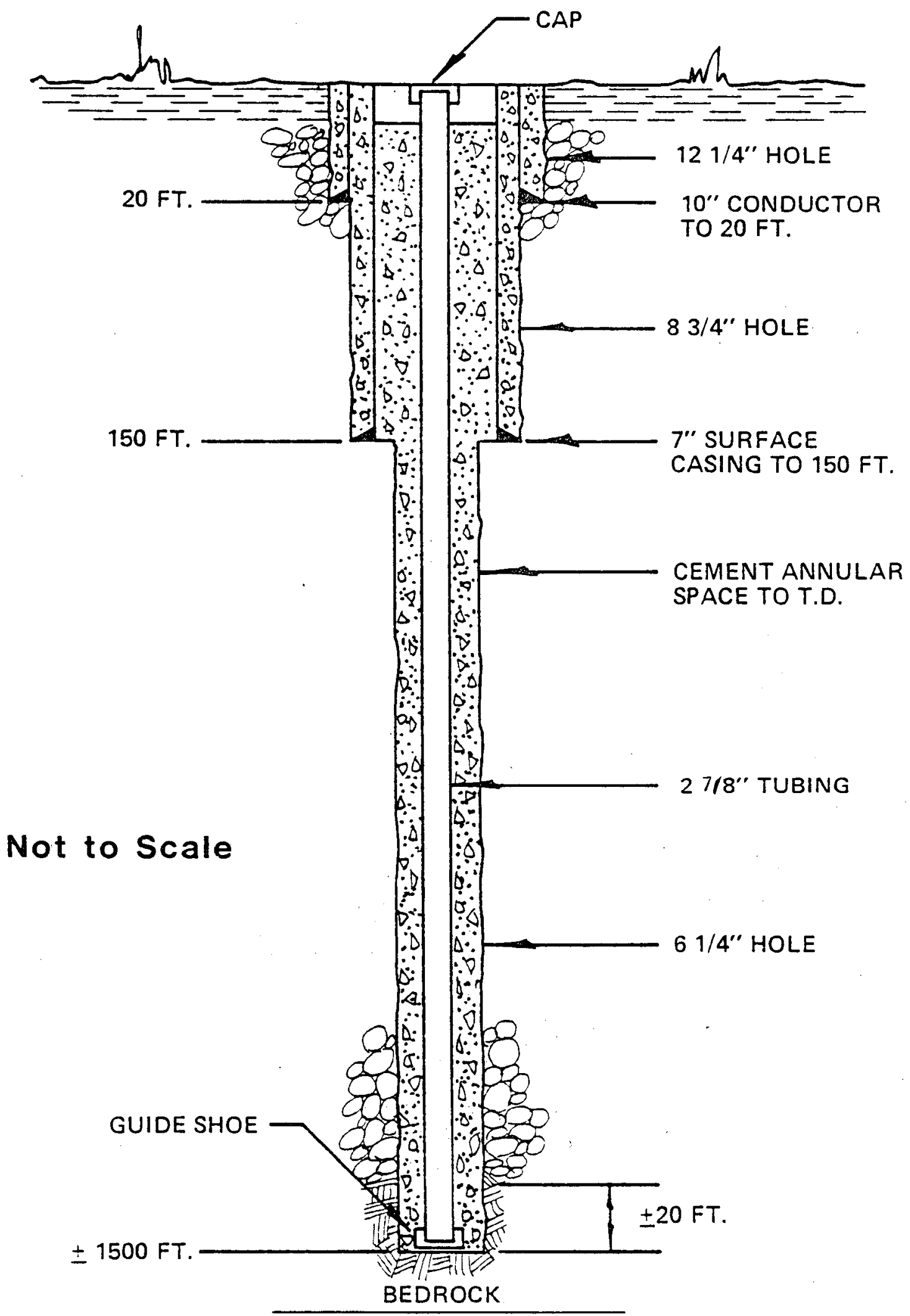


The location of the production well to be drilled was to be determined after review of thermal gradient drilling results, geology, flow rates, and 1 and ownership information. The two most important factors in selecting the site are resource temperature and the attainable flow rate. The other variables to consider are the distance between the production well and the wastewater treatment plant, and the degree of difficulty involved in placement of transmission pipeline facilities.

\subsection{Permits and Agreements.}

In order to conduct the drilling program and place thermal gradient wells on the non-department owned land, agreements were negotiated with two local agencies. A permit was obtained from the San Bernardino County Flood Control District granting permission to construct up to two thermal gradient wells on the west levee of Twin Creek Channel. A second agreement was entered into with the National Orange Show to conduct exploratory drilling for up to three thermal gradient wells. Agreement could not be reached for the placement of a production well upon National Orange Show property; however, permission granted from the two agencies provided sufficient land area for optimum placement of thermal gradient/observation wells along or near the Loma Linda Fault.

Notices of Intent to Drill a Geothermal Resource Well were submitted to the State of California, Division of Oil and Geology for four thermal gradient well sites in December, 1981. Included with the notices was a copy of the intended drilling program for review and approval.

A Notice of Exemption was issued in December, 1981 for the drilling of

up to five thermal gradient wells by the Division of Oil and Gas, fulfilling the CEQA requirements for the first phase of the drilling program.

Reports on Proposed.Geothermal Operations for the four thermal gradient wells were issued by the Division of Oil and Gas in February, 1982. 


\subsection{Selection of Drilling Contractor.}

Plans and specifications were developed by November, 1981 for the drilling and development of up to five thermal gradient wells on a lump-sum basis. Authorization was granted from the Board of Water Commissioners to advertise and receive bids for the drilling of the thermal gradient wells. Bids received were opened on December 30, 1981. A review of the bids received was conducted by Water Department staff and representatives from Republic Geothermal, Inc. It was the general concensus that the lump sum bids should be rejected, and the specifications modified to receive bids on a time and material basis, thereby putting more risk on the Water Department to reduce the contractual costs of drilling. The four drilling contractors who bid on the project related that they were reluctant to competively bid due to four conditions: (1) shallow groundwater; (2) areas of large boulders that appear on other well logs within the drilling area; (3) artesian pressure; and (4) unknown water temperature.

As a result of the information obtained, the bids for drilling up to five thermal gradient wells were rejected by the Board of Water Commissioners, and authorization was granted to modify the specifications and advertise and receive bids on a time and material basis. Bids were received for the drilling program again and on February 2, 1982, the contract was awarded to McCalla Bros., Inc. Republic Geothermal, Inc. was retained to provide field supervision, and to conduct all logging and testing requirements for the thermal gradient wells.

\subsection{Drilling, Logging, Completion of Thermal Gradient Wells.}

The thermal gradient drilling program began March 16, 1982 and concluded on May 11, 1982. During that period, four thermal gradient wells were drilled, logged, and cased. The four wells (TG-2, TG-1, TG-5A, and TG-4A) were drilled to depths ranging from 815 to 1500 feet. Drill cuttings were sampled at nominal ten foot intervals. In addition, open hole intervals were logged for selfpotential and resistance in TG-2, TG-1, and TG-5A using a Mt. Sopris Model 1000-C portable logging unit and, in TG-4A, with a Gearhart-Owens unit by 
Southwest Drilling Company. Under conditions in which the 1000-C tool could not be used, holes were gamma ray logged through the 2-7/8 inch tubing and cement.

To obtain accurate temperature measurements and to isolate thermal aquafers later in the project, 2-7/8 inch capped tubing was installed in each hole and pressure grouted from bottom to top by Halliburton Services.

\subsubsection{Stratigraphic Summary.}

The stratigraphy of the project area, to the depths drilled in the four temperature gradient/observation wells, comprises two units: The Tertiary Age San Timoteo Formation and the overlying Quaternary Age Santa Ana River alluvium. Both are composed of intercalated beds of unconsolidated coarse angular sands, grave1s, clays, and all gradations between the three. No alteration, cementation, or grain coatings were noted. Discrete beds are usually two to ten feet thick; however, some sands are up to 45 feet thick. Both the alluvium and the San Timoteo sediments were deposited in stream channels and on adjacent river banks (alluvial plains).

The salient features of each hole are submitted and attached as Appendixes B-D. Plates II - V, shown in Appendix A, depict the detailed stratigraphy and serve to document the impossibility of correlating beds between the thermal gradient wells. Figure 3 is a structure contour map drawn on top of the San Timoteo Formation. The map is based on the depth to the top of the San Timoteo Formation in each of four gradient holes drilled, indicating that the San Timoteo Formation dips about 7 degrees to the west in this area.

\subsubsection{Geologic Structure and Distribution of Thermal Waters.}

The relative unconsolidated nature of the rocks penetrated by the four wells, together with their origin within braided stream channels whose courses of ten shift in time and in space, create a situation wherein it is almost impossible to accurately determine the attitude of the sediments. The incom- 


\section{FIGURE 3 \\ STRUCTURE CONTOUR MAP \\ ON TOP OF THE SAN TIMOTEO Fm}




petence of these units precludes the direct detection of faults that transect the area. Plates VI and VII, as shown in Appendix A, are geologic cross sections that depict interpreted stratigraphic, structrual, and thermal conditions in the project area.

It appears likely that the locations of the old Warm Creek Channel and of its main northeasterly trending tributary may be fault-controlled and that these faults intersect the northwest-trending Loma Linda fault in the vicinity of the Meeks \& Daley 非6 well. This fault intersection probably provides a "high" permeability path that allows the warm thermal fluids to rise to shallow depths or even to the surface, as suggested by the name Warm Creek. This theory is supported by the temperature distribution of fluids encountered in existing water wells that, southeastward along most of the Loma Linda fault in this area, become much cooler than those flowing from the Meeks \& Daley \#66. The exception to this trend is in an area to the southeast of the Wastewater Treatment Plant, on the golf course, where the well water temperatures are also high (well 非1, $51^{\circ} \mathrm{C}$ ). This fact suggests the presence of a second fault orthogonally intersecting the Loma Linda fault and creating conduits for upward percolation of hotter waters.

Simultaneous analyses of the temperature profiles and the 1ithologies recorded in the gradient holes (Plates II-V) show that there are several discrete aquifers having different temperatures at varying depths within both the alluvium and the San Timoteo Formation. Figure 4 is a map of the maximum temperatures measured in the four gradient holes and in the Meeks \& Daley 非6, contoured without regard to depth. The contour pattern confirms that temperatures decrease to the southeast and east away from the Meeks \& Daley 非66 and TG-2 area.

These data reinforce the theory that the thermal fluids are rising in the area of the Loma Linda and Warm Creek fault intersection and then flowing into a number of separate cold water aquifers in varying amounts. The variable mixing rates, permeabilities of the aquifers, and rates of water movement within each aquifer account for the variable temperature distribution east and southeast of the source area near Meeks \& Daley $\# 66$. 


\section{MAXIMUM TEMPERATURE CONTOUR MAP}

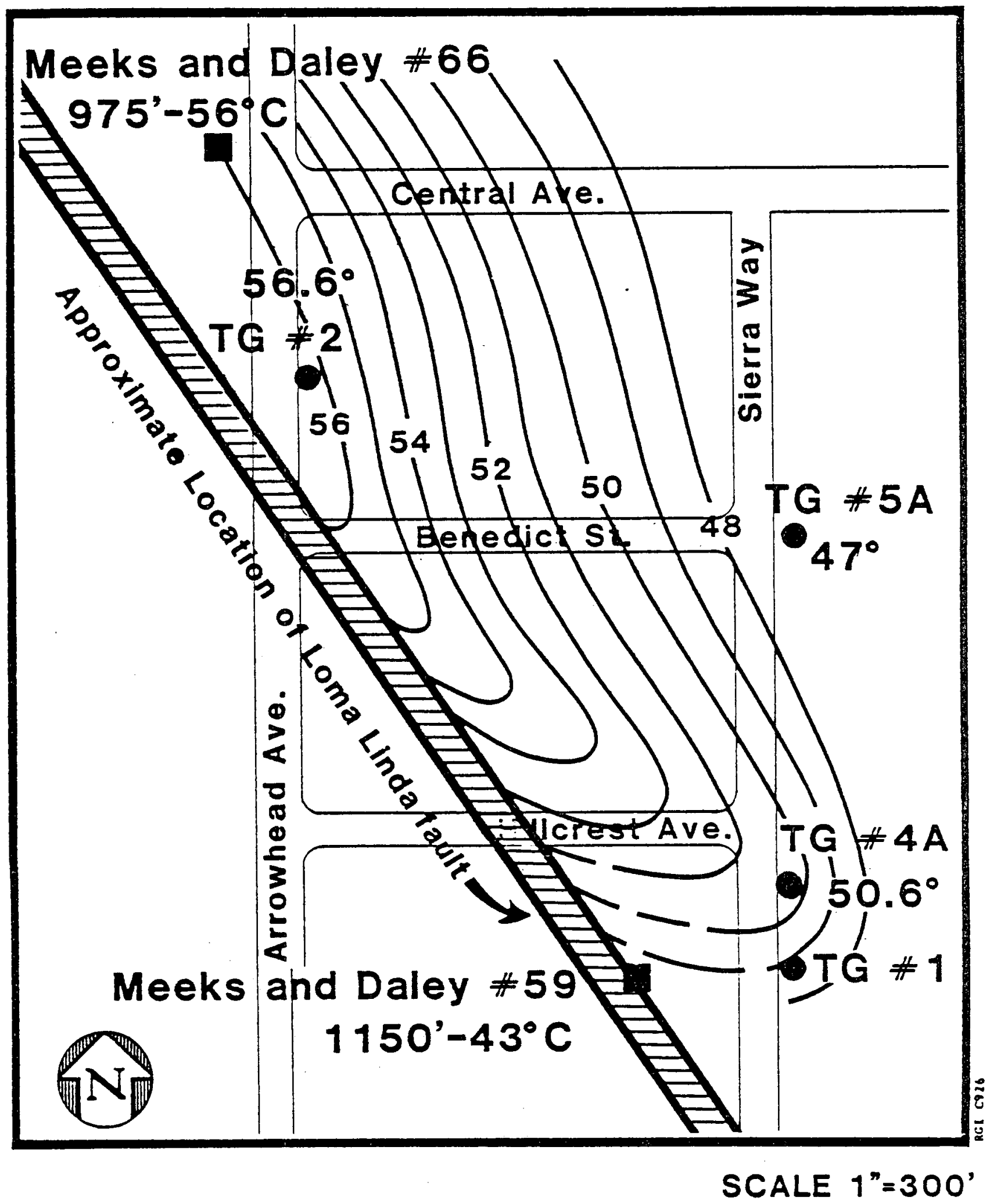


The Loma Linda fault apparently acts as an aquiclude along its strike and may deflect the thermal waters toward the east and southeast. This is supported by available water well data that show that there is no apparent thermal plume spilling across the fault to the west.

\subsubsection{Hydrology of Thermal Waters.}

Analyses of both the stratigraphic and temperature data lead to a conclusion that the distribution of thermal waters in the project area is controlled primarily by the location of the Loma Linda fault and by its intersection(s) with at least one (and probably two) northeast-striking fault(s). Of secondary importance is, of course, the distribution of permeable horizons adjacent to and transected by the Loma Linda fault.

As has been previously noted, TG-2 appears to be located near a thermal water upwelling site that may exist at the junction of the Loma Linda and Warm Creek faults. Warm $\left(56^{\circ} \mathrm{C}\right)$ waters tapped in the Meeks and Daley 非6 and in TG-2 tend to flow southeastward along the semipermeable to impermeable boundary created by the Loma Linda fault. They were encountered at varying depths in $T G-5, T G-4 A$, and $T G-1$, and at varying temperatures, a11 of which were cooler than $56^{\circ} \mathrm{C}$.

It appears then that the waters tapped in the latter three wells were mixed to varying degrees with nonthermal waters that saturate both the alluvium and the San Timoteo sediments in areas away from the Loma Linda fault.

The hydrothermal system in the project area is more complicated than was initially suspected so that with the limited factual information available, conclusions can be drawn only on broad hydrologic principals. Nevertheless, the system described above is consistent with the data recorded and sound decisions can be made concerning the best site for the production well. 


\subsubsection{Recommendations for Production Well.}

Based upon the results obtained from the thermal gradient well drilling program, the recommended site for drilling a production well was \pm 250 feet northwest of Meeks and Daley $\# 66$. This location was selected to be the most cost effective with regard to resource temperature and logistics of the transmission pipe from the well site to the Wastewater Treatment Plant. The pilot hole was to be drilled to a depth of 1,000 feet, logged, and then a determination made as to the depth of the production well and the production interval. The anticipated temperature of the resources was $56^{\circ} \mathrm{C}\left(133^{\circ} \mathrm{F}\right)$ or slightly higher.

An alternate site \pm 20 feet north of $\mathrm{TG}-2$ was selected if access could not be gained to the primary site. The anticipated resource temperature at the alternate site was $56^{\circ} \mathrm{C}$ or higher. 


\section{ACQUISITION OF PRODUCTION WELL AND INSTALLATION OF TRANSMISSION LINES.}

With the drilling program complete and the optimum location of a production well known, the next objective was to acquire the right to drill a production well on the proposed well site. The property is owned by the National Orange Show. Previous agreement had been reached with the Board of Directors for the National Orange Show for the drilling of up to three thermal gradient/ observation wells. Numerous delays were encountered in trying to reach an agreement with the National Orange Show for use of their property. With the delays encountered, an alternate site for placement of a production well was selected. The site, located \pm 250 feet west of Meeks and Daley 1 k6 6 on property adjacent to Warm Creek Channe1, is owned by the San Bernardino County Flood Control District. A permit was granted by the District for the construction of a well and appurtenant facilities in September, 1982 for a twenty year period. By obtaining the use of this site, the only obstacle that remained was obtaining a pipeline easement from the well site to Arrowhead Avenue on property owned by the National Orange Show.

\subsection{Acquisition of Production We11.}

Contact with Meeks and Daley Water Company had been made at the start of the project to determine if there was a possibility of acquiring Meeks and Daley 非6. At the time, they were not interested in selling Meeks and Daley \#66. It was also anticipated that the drilling program would locate a resource with a higher temperature.

With the results of the resource confirmation program and delays in obtaining rights to drill a production well on National Orange Show property, contact was made again with Meeks and Daley Water Company for the acquisition of Meeks and Daley $\$ 66$ well. Negotiations began in August, 1982 and agreement was reached in November, 1982 for the acquisition of Meeks and Daley 非6 and an area around the well to connect it to the site obtained from the San Bernardino County Flood Control District. The total acquisition cost for the well and plot of 1 and was $\$ 40,000$ (Figure 5). 
Meeks and Daley $\$ 66$ was drilled by cable tool in 1966 to a total depth of 975 feet according to the drilling $\log$ (Table 1). The proposed use of the well was for domestic and irrigation water. The well was backfilled from 700 feet to 975 feet apparently in an effort to seal off strata containing elevated boron. The well was cased throughout the depth of the hole with 20-inch diameter 6 gauge casing perforated at all hot and cold water bearing strata, using a Mills Mechanical Knife with a $2 \frac{1}{2}$ inch by $3 / 8$ inch blade.

In approximately 1977, the well began to flow artesian at a rate of 1,350 $\mathrm{gpm}$, with a water temperature of $135^{\circ} \mathrm{F}$ to $140^{\circ} \mathrm{F}$. Geothermal Surveys, Inc. attempted a thermal $\log$ in May, 1980. The results are displayed in Table 2 . The well could only be logged to a depth of 160 feet due to the artesian flow and the large diameter pump equipment set inside the casing.

\subsection{Rework of Meeks and Daley 非6.}

Upon entering escrow for the purchase of Meeks and Daley $\$$ 66, authorization was granted by Meeks and Daley Water Company for the Water Department to remove the existing pumping equipment, bail the well, and set equipment to conduct carbon dioxide vapor pressure testing.

The last week of December, 1982, the existing equipment was pulled from the well and the well was then bailed to a total depth of 945 feet from 857 feet. The carbon dioxide release test was then conducted on the well by setting a $35 \mathrm{gpm}, 100 \mathrm{psi}$ submersible pump $60 \mathrm{feet}$ into the well which was flowing in excess of 1,000 gpm. The preliminary findings indicate a carbon dioxide vapor pressure of 8 to 9 psi.

In January, 1983, flow tests were conducted on the well. In order to conduct the flow and temperature tests, a valved 12-inch diameter pipe was inserted in the 20-inch diameter well casing and a well seal kit was inflated to control the artesian flows. Results of the first flow and temperature tests are displayed on Table 3. The temperature remained at $55^{\circ} \mathrm{C}$ at flows varying from $500 \mathrm{gpm}$ up to $2,500 \mathrm{gpm}$. 
STATE \#E-966b

TABLE I

MEEKS AMD QALEY WATER COMPANY

60.0 feet West of Arrowhead Avenue - 90.0 feet North of Central Avenue

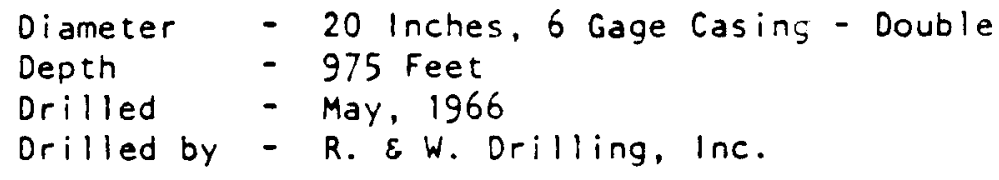

\begin{tabular}{|c|c|c|c|c|c|}
\hline $\begin{array}{r}0 \\
60\end{array}$ & $\begin{array}{l}\text { Ft. } \\
\text { Ft. }\end{array}$ & $\begin{array}{l}\text { to } \\
\text { to }\end{array}$ & $\begin{array}{l}60 \\
64\end{array}$ & $\begin{array}{l}F t . \\
F t .\end{array}$ & $\begin{array}{l}\text { sand and gravel } \\
\text { clay }\end{array}$ \\
\hline 64 & Ft. & to & 210 & $\mathrm{Ft}$. & blue silt and sand \\
\hline 210 & $F t$. & to & 220 & Ft. & gravel and rock - up to 4 inches \\
\hline 220 & $F t$. & to & 244 & $\mathrm{Ft}$. & blue clay and gravel \\
\hline 244 & Ft. & to & 255 & Ft. & gravel and rock - up to 4 inches \\
\hline 255 & Ft. & to & 262 & $\mathrm{Ft}$. & brown clay and gravel \\
\hline 262 & Ft. & to & 280 & Ft. & brown clay \\
\hline 280 & Ft. & to & 290 & Ft. & small gravel \\
\hline 290 & $F t$. & to & 310 & $\mathrm{Ft}$. & brown clay and gravel \\
\hline 310 & Ft. & to & 315 & Ft. & sand and gravel \\
\hline 315 & $\mathrm{Ft}_{\text {t. }}$ & to & 351 & Ft. & brown clay and gravel \\
\hline 351 & $\mathrm{Ft}$. & to & 379 & $\mathrm{Ft}$. & blue clay and sand with streaks \\
\hline 379 & Ft. & to & 385 & Ft. & blue clay \\
\hline 385 & Ft. & to & 387 & $\mathrm{Ft}$. & brown sand, fine \\
\hline 387 & $F t$. & to & 398 & Ft. & blue fine sand, tight \\
\hline 398 & Ft. & to & 415 & Ft. & blue clay with gravel streaks \\
\hline 415 & Ft. & to & 450 & Ft. & blue sandy clay \\
\hline 450 & Ft. & to & 461 & Ft. & cemented sand and gravel \\
\hline 461 & $F t$. & to & 467 & $F t$. & blue sandy clay \\
\hline 467 & $\mathrm{Ft}$. & to & 503 & $F t$. & blue sandy clay with gravel \\
\hline 503 & $F t$. & to & 570 & Ft. & brown sand an: gravel \\
\hline 570 & $\mathrm{Ft}$. & to & 575 & $F t$. & brown sand and gravei - up to 4 inches \\
\hline 575 & Ft. & to & 612 & Ft. & brown sandy clay \\
\hline 612 & Ft. & to & 617 & $\mathrm{Ft}$. & black sticky clay \\
\hline 617 & $F t$. & to & 635 & Ft. & brown clay \\
\hline 635 & Ft. & to & 695 & $\mathrm{Ft}$. & gray sand and gravel - up to 4 inches \\
\hline $\begin{array}{l}695 \\
703\end{array}$ & Ft. & to & 703 & Ft. & ticht sand, small gravel, brown clay \\
\hline 745 & $\mathrm{Ft}$. & to & 793 & Ft. & $\begin{array}{l}\text { tight sand and small gravel } \\
\text { silt, fine sand with blue clay }\end{array}$ \\
\hline 791 & Ft. & to & 801 & Ft. & cemented sand and pea gravel \\
\hline 301 & $F t$. & to & 809 & $F t$. & tight sand and small gravel \\
\hline 809 & $\mathrm{Ft}$. & to & 867 & $\mathrm{Ft}$. & sand and gravel - up to 4 inches \\
\hline 867 & Ft. & to & 885 & $\mathrm{Ft}$. & sand and gravel - tight, clean \\
\hline 8 & $\mathrm{Ft}$. & to & 930 & Ft. & sand, pea gravel - tight with clay \\
\hline 9 & Ft. & to & 939 & Ft. & sand and gravel, small \\
\hline 939 & $\begin{array}{l}\text { Ft. } \\
\text { Ft. }\end{array}$ & to & 955 & Ft. & sand and gravel and rocks \\
\hline & Ft. & to & 975 & $\begin{array}{l}\text { Ft. } \\
\text { Ft. }\end{array}$ & $\begin{array}{l}\text { sand, silt with streaks of clay } \\
\text { brown and blue clay }\end{array}$ \\
\hline
\end{tabular}

Driller's Log from Meeks and Daley Well No. 66 
Thermal Survey Data from Meeks and Daley Well No. 66*

Flow:

(Artesian)

Temperature at outflow:

Field pH

Temperature at depth:

$$
\begin{aligned}
& 20 \mathrm{ft} .-\begin{array}{r}
63.1^{\circ} \mathrm{C} \\
145.6^{\circ} \mathrm{F}
\end{array} \\
& 160 \text { ft.- } \begin{array}{r}
63.0^{\circ} \mathrm{C} \\
145.4^{\circ} \mathrm{F}
\end{array}
\end{aligned}
$$

Thermal Gradient:

\section{$875 \mathrm{gpm}$}

$55^{\circ} \mathrm{C}$

$$
7.0
$$

$20-160 \mathrm{ft}-.07^{\circ} \mathrm{C} / 100 \mathrm{ft}$.

$.13^{\circ} \mathrm{F} / 100 \mathrm{ft}$.

*From analysis performed by Geothermal surveys, Inc. in May 1980. 
TABLE 3

TEMPERATURE AND FLOW TEST

MEEKS \& DALEY \#66

January 8,1983

Flow

Rate

(GPM)

500 Temperature $\left({ }^{\circ} \mathrm{F}\right)$

Pressure (psi)

$\mathrm{pH}$

1,000 Temperature $\left({ }^{\mathrm{F}}\right)$

Pressure (psi)

$\mathrm{pH}$

1,500 Temperature $\left({ }^{\mathrm{O}}\right)$

Pressure (psi)

$\mathrm{pH}$

2,000 Temperature $\left({ }^{\circ} \mathrm{F}\right)$

Pressure (psi)

$\mathrm{pH}$

2,500 Temperature $\left({ }^{\mathrm{O}} \mathrm{F}\right)$ Pressure (psi) $\mathrm{pH}$
MINUTES AT FLOW RATES

\begin{tabular}{rrrrrr}
\multicolumn{1}{r}{5} & \multicolumn{1}{c}{10} & \multicolumn{1}{c}{15} & \multicolumn{2}{c}{$\underline{20}$} & \multicolumn{2}{c}{$\underline{25}$} & \multicolumn{1}{c}{$\underline{30}$} \\
127.00 & 128.00 & 128.00 & 128.00 & 129.00 & 131.00 \\
12.00 & 11.75 & 11.75 & 11.75 & 11.75 & 11.75 \\
8.25 & 8.25 & 8.30 & 8.22 & 8.25 & 8.30
\end{tabular}

130.60

129.90

129.80

129.90

130.00

130.00

10.50

10.00

10.00

10.00

10.00

10.00

8.25

8.25

8.25

8.35

8.62

8.62

130.70

131.00

131.00

131.00

131.00

131.00

9.00

8.50

8.50

8.50

8.50

8.50

8.30

8.62

8.62

131.20

7.00

131.10

131.00

131.00

131.00

131.00

8.82

6.75

6.75

6.75

6.75

8.82

8.82

$\begin{array}{rr}131.00 & 131.00 \\ 4.50 & 4.50 \\ 8.88 & 8.88\end{array}$

$\begin{array}{rr}131.00 & 130.90 \\ 4.50 & 4.50 \\ 8.86 & 8.86\end{array}$
130.90
4.50
8.80

130.90

4.50

8.86

Static Start: Pressure: $12.5 \mathrm{psi}$

Start Temperature:

Time to sand surge:

$110.0 \mathrm{~F}$

Well Seal Bag Pressure: 24.0 psi

Start Time:

Finish Time:

10.30 a.m.

$2: 45$ p.m. 
Temperature profiles for Meeks and Daley $\$$ 作6 are displayed on Figure 6 . Because the well was flowing, the temperature curve is relatively flat. The highest temperature recorded was $59^{\circ} \mathrm{C}$ at a depth of 825 feet. More recent temperature profiles were conducted and are displayed in Appendix F.

Subsequent to the initial tests performed, the well head was reequipped to allow for total shut off of the well. A blind flange was installed on top of the casing and three gate valves on the 20-inch casing to allow for controlled flows to the treatment plant, discharge to the Flood Control Channel, and a valve for an additional transmission line connection.

\subsection{Transmission Pipeline Installation.}

In June, 1983, contact was made with various suppliers of insulated pipe to obtain a better working knowledge of the various products and estimated costs. After review of the products and literature, formal specifications were developed for furnishing 4400 feet of 8 -inch insulated pipe.

The design criteria for determining pipe size are displayed on Table 4.

TABLE 4

DESIGN CRITERIA FOR DETERMINING PIPE DIAMETER

Number of digesters to be heated: $2-2$ million gallon capacity.

Maximum day heat requirement per digester: $1.5 \times 10^{6} \mathrm{Btu}^{\prime} \mathrm{s}$.

Flow requirement based on an exchange $\Delta^{t}$ of $16^{\circ} \mathrm{F}: 500 \mathrm{gpm}$.

Distance from well to digester: 4200 feet.

Coefficient of roughness for epoxy-1ined pipe: 130 (c).

Maximum acceptable head loss in 4200 feet of pipeline: 25 feet.

Maximum allowable heat 1 oss a $500 \mathrm{gpm}: 1^{\circ} \mathrm{F}$ in 4200 Feet. 
A contract was awarded in February, 1983 to Thermal Pipe System, Inc. for 4400 feet of 8-inch inside diameter epoxy-lined preinsulated and cased pressure pipe manufactured by Johns-Mansville Corporation. The core pipe is Class 150 Asbestos Cement pressure pipe with a Class 1500 Asbestos Cement sewer pipe casing. The pipe has ring-tite joints allowing for fast and simple installation.

Within two weeks of contract award, the pipe was delivered by the supplier. To facilitate the installation, the Water Department scheduled two crews for the project. One crew started at the heat exchangers located at the Wastewater Treatment Plant, and the other crew started at the well site. Installation of the pipeline within the Treatment Plant property took longer than planned due to a high groundwater table and the large number of underground pipes within the transmission pipeline route. Thirty-two underground utility lines were encountered, and the groundwater table was within three feet of the surface. Air release valves were installed along the pipeline to prevent air locking caused by carbon dioxide vapor release from the geothermal fluid. A coaxial cable was installed within the same pipeline trench, from the heat exchanger to the well for instrumentation and controls. The pipeline installation was completed the first week of April, 1983.

The pipeline route is located along the western edge of Arrowhead Avenue. The route is located within the right-of-way but off of the paved area to avoid the cost of repaving the street and to reduce conflict with the number of underground utilities in the area. A utility easement was obtained for the area between Orange Show Road and the Wastewater Treatment Plant property to provide the most direct route for the transmission pipeline. Figure 7 displays the pipeline route. 


$$
4 \text { - SYSTEM DESIGN, TESTING, START-UP }
$$

All major construction activities for the project were completed to a level where the system could be tested by April 3, 1983. Official dedication ceremonies were conducted on April 5, 1983 by the Board of Water Commissioners. The system was designed with the capabilities of heating up to three 2 million gallon anaerobic digesters. The phase completed is heating one of the 2 million gallon digesters.

\subsection{System Design.}

A piping and instrumentation diagram appears as Figure 8 for heating one anaerobic digester with geothermal fluid from Meeks and Daley 非6. The symbols used for the diagram are identified in Table 5 .

\subsubsection{Heat Exchanger.}

The preliminary design for heating the anaerobic digester with geothermal fluids at $145^{\circ} \mathrm{F}$ required a 200 square foot spiral plate heat exchanger. This design transfers 1.5 million Btu's/hr of heat to digester sludge.

When the actual temperature of the resource was known, contact was made with the manufacturer of the existing spiral plate heat exchanger to determine if it could be used. The existing heat exchanger is a Model $160 \mathrm{H}$ Spiral Sludge Heat Exchanger manufactured by Alfa-Laval.

Representatives from Alfa-Laval indicated that the existing sludge heat

exchanger could utilize the $134^{\circ} \mathrm{F}$ geothermal fluid to heat the sludge from the digesters. A very important criteria evaluated in utilizing the geothermal fluid in the existing heat exchanger was the quality of the geothermal fluid. An analysis was performed with the results displayed on Table 6 . The fluid was of the same or better quality than the treated water used in the boiler system; therefore, it was determined that it would not foul or clog the heat exchanger. 
(To/From Existing Boiler/Heat Exchanger System)

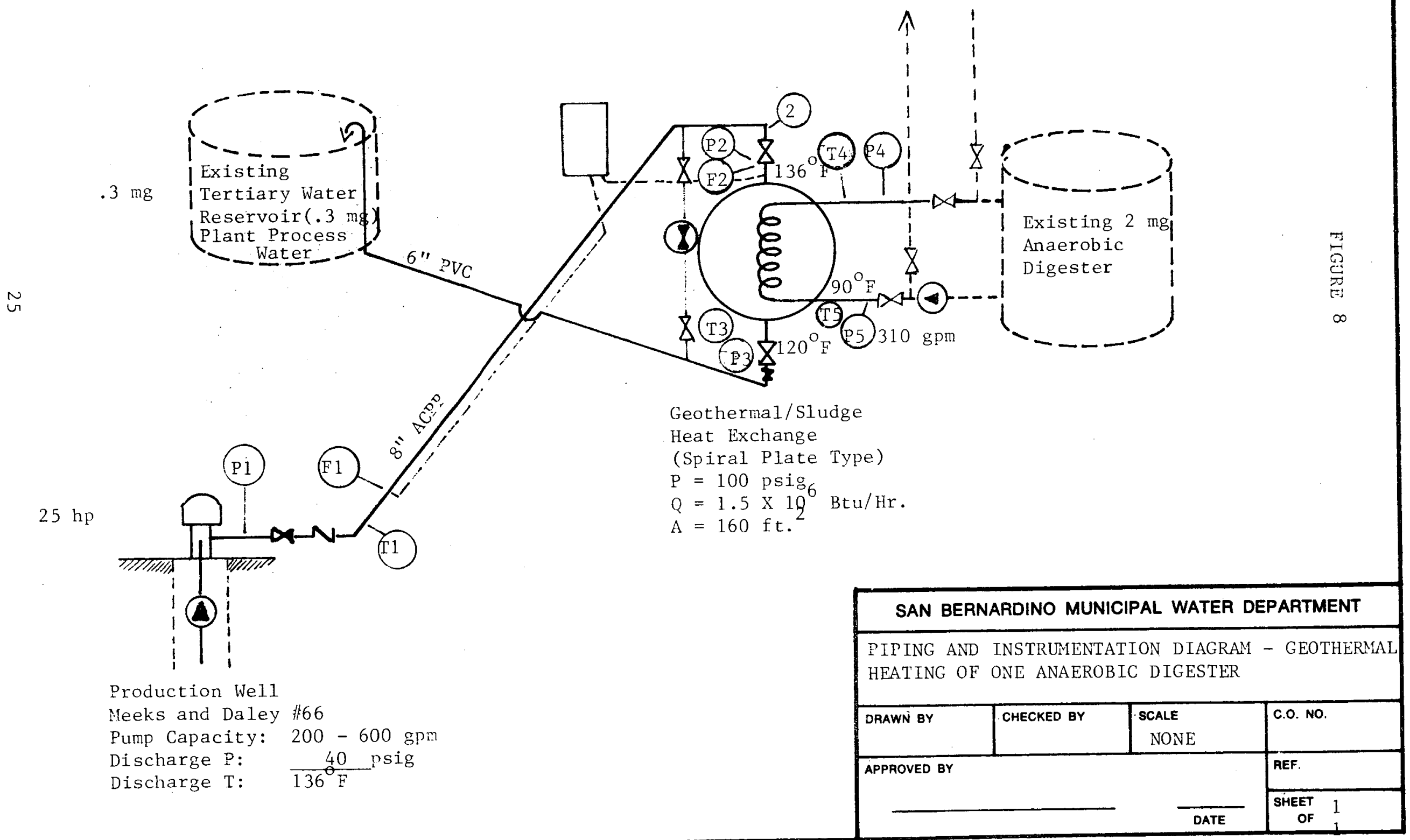


TABLE 5

KEY TO DRAWING SYMBOLS

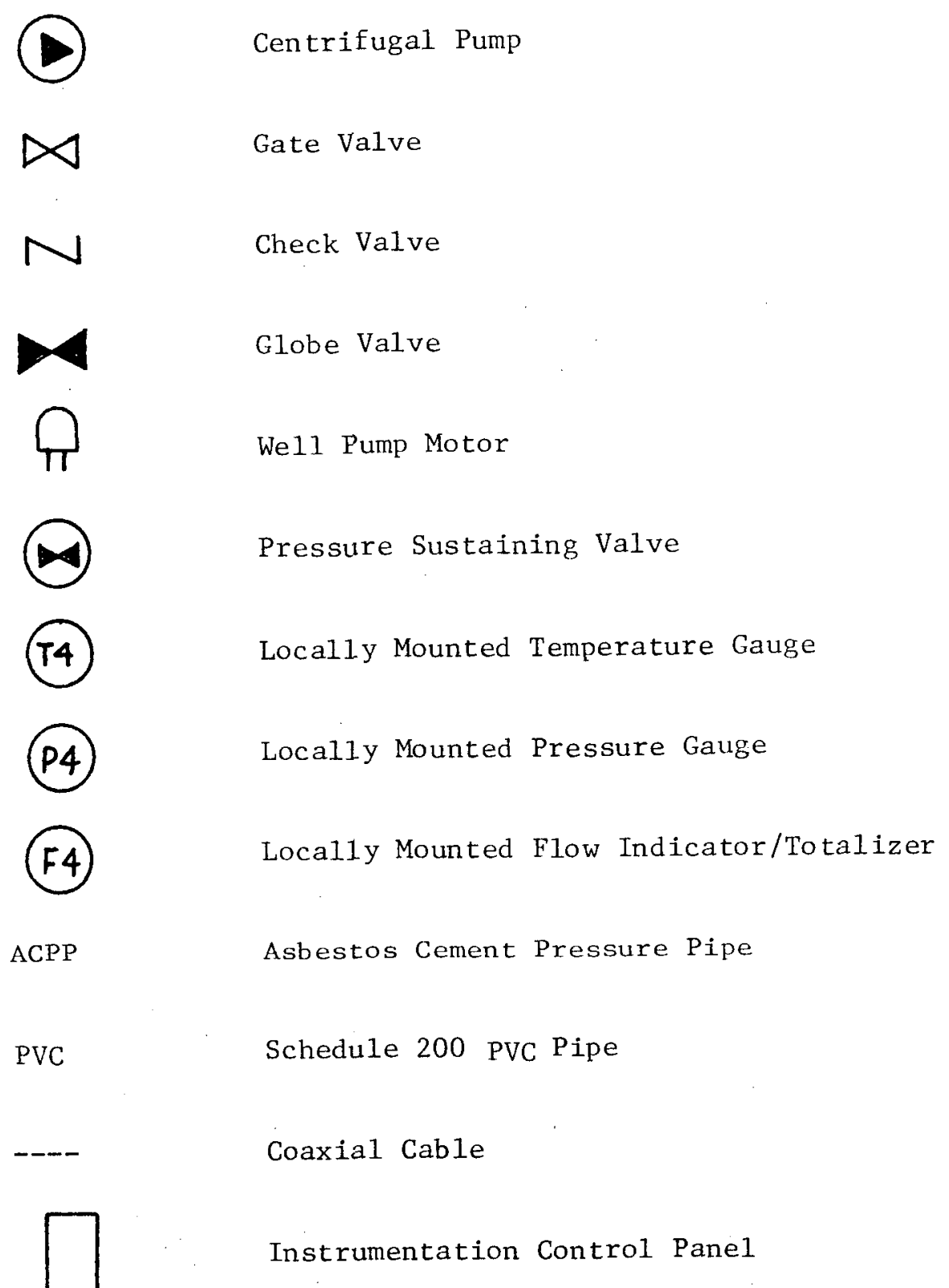


TABLE 6

ANALYSIS OF WATER SAMPLES FROM THE MEEKS AND DALEY WELL NO. 66

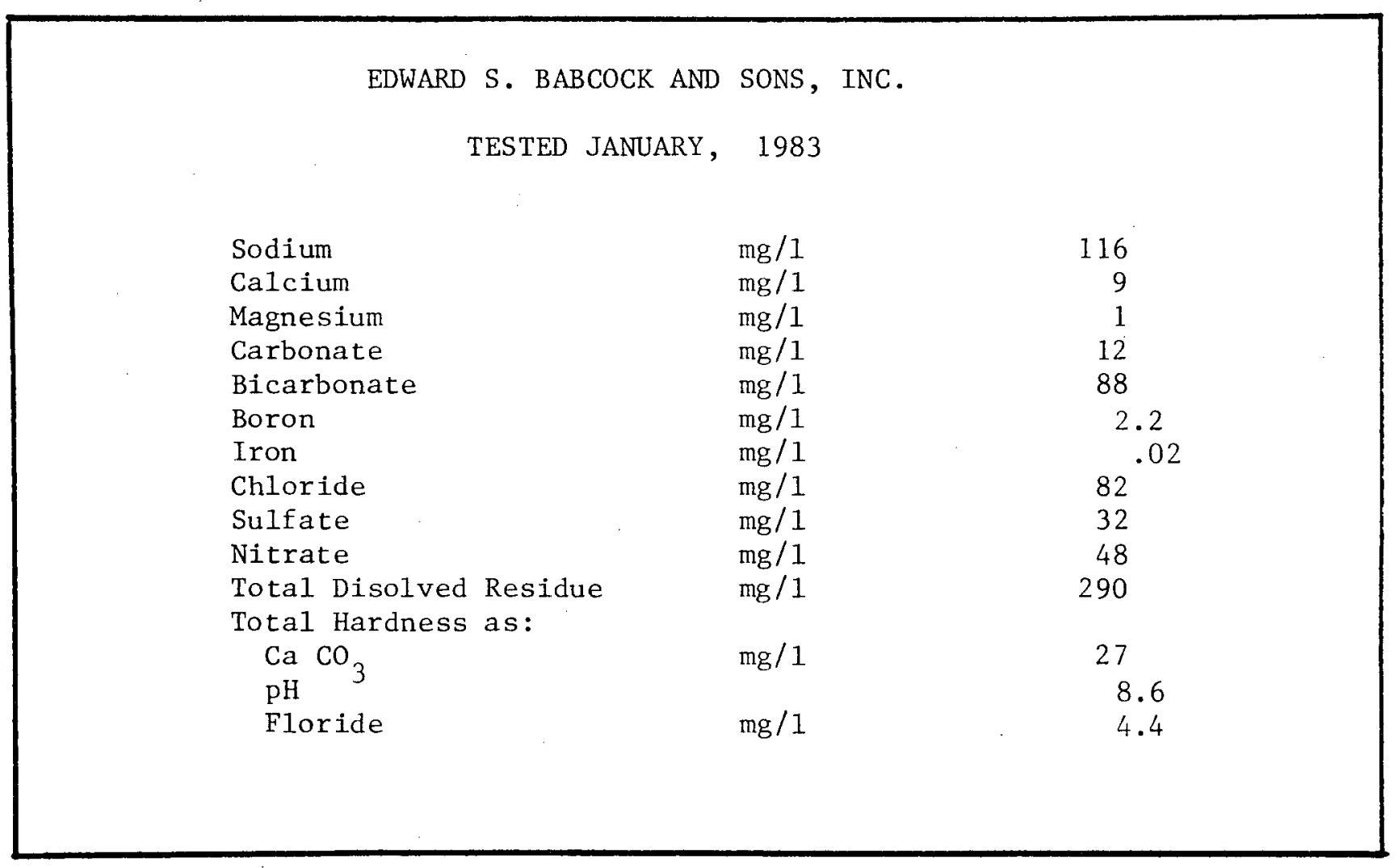


The existing heat exchanger is a 150 square feet "sludge type" spiral heat exchanger fabricated of $1 / 4$ inch carbon steel. The original design criteria are listed below:

SLUDGE $\quad$ WATER

Capacity Btu/Hr

Flow GPM

Inlet Temperature ${ }^{\circ}{ }_{\mathrm{F}}$

Pressure drop in feet of water
$1,530,000$

306

90

100

10
306

155

145

Water Department staff conducted flow tests utilizing the geothermal fluid to determine if the existing heat exchanger would work. The average requirement for the east digester during the test period was 700,000 Btu's per hour. The maximum heat requirement is 1.5 million Btu's per hour. Testing was conducted under two conditions. The first test was conducted when the well was flowing artesian with a maximum flow rate of $165 \mathrm{gpm}$. Results of the test are displayed on Table 7. A second test was conducted after a pump was installed on Meeks and Daley $\$$ 66 wel1. Results of the test are displayed on Table 8 . Test results indicate the existing heat exchanger is sufficient to transfer the required heat from the geothermal fluid to the sludge.

4.1.2 Pump and Motor - Meeks and Daley \#66.

Meeks and Daley $\$$ 66, acquired in January, 1983, has been and continues to flow artesian. The rate of flow has been as high as 3,000 gpm during the winter months when most other wells in the artesian pressure zone are not operating. During April, 1983, the well developed a static pressure of 20 psi. With this condition, sufficient flow and pressure existed to utilize the geothermal energy without pumping. Other wells in the vicinity were turned on as the demand for water increased, and the artesian flow decreased to less than 1,000 gpm with 4 to 5 psi residual pressure. This condition does not permit gravity flow use of the geothermal energy at the Wastewater Treatment Plant. 
FLOW TEST ON EAST DIGESTER

HEAT EXCHANGE

MEEKS AND DALEY 非66 WELL FLOWING ARTESIAN

\begin{tabular}{|c|c|c|c|c|c|c|c|c|c|c|c|c|c|c|}
\hline \multirow[b]{2}{*}{ 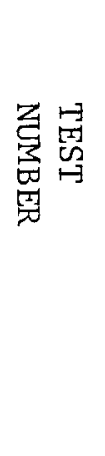 } & \multicolumn{7}{|c|}{ SLUDGE DATA } & \multicolumn{7}{|c|}{ GEOTHERMAL FLUID DATA } \\
\hline & 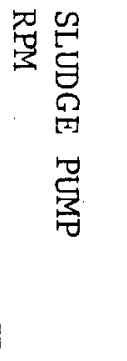 & 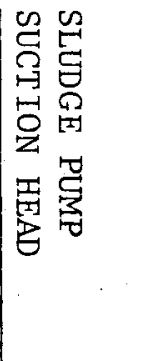 & 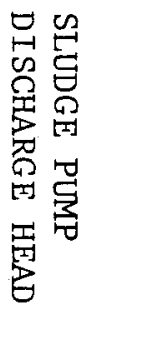 & 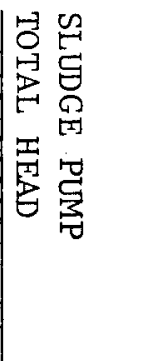 & 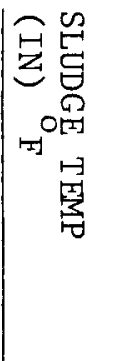 & 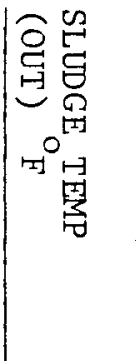 & 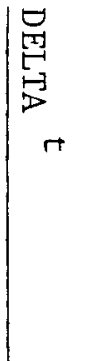 & 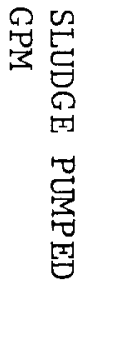 & 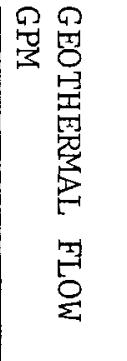 & 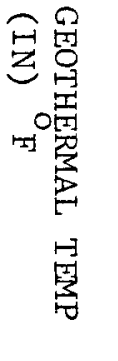 & 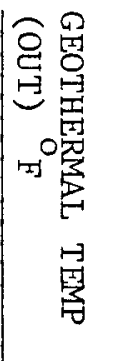 & 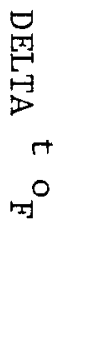 & 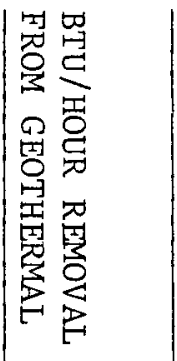 & 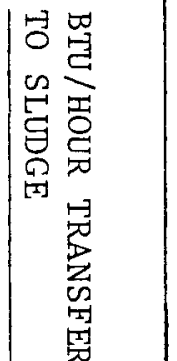 \\
\hline 1. & 740 & 18.48 & 34.65 & 16.17 & $92^{\circ}$ & $94^{\circ}$ & $2^{0}$ & 490 & 80 & $131^{\circ}$ & $114^{\circ}$ & $17^{\circ}$ & 680,544 & 490,392 \\
\hline 2. & 840 & 17.78 & 42.70 & 24.90 & $90^{\circ}$ & $96^{\circ}$ & $6^{\circ}$ & 250 & 90 & $130^{\circ}$ & $114^{\circ}$ & $16^{\circ}$ & 720,576 & $750,600 \mid$ \\
\hline 3. & 840 & 17.78 & 42.70 & 24.90 & $90^{\circ}$ & $97^{\circ}$ & $7^{\circ}$ & 250 & 130 & $130^{\circ}$ & $116^{\circ}$ & $14^{\circ}$ & 910,728 & $|875,700|$ \\
\hline 4 . & 900 & 16.17 & 43.90 & 27.70 & $90^{\circ}$ & $96^{\circ}$ & $6^{\circ}$ & 270 & 130 & $130^{\circ}$ & $117^{\circ}$ & $13^{\circ}$ & 845,676 & $810,648 \mid$ \\
\hline 5. & 740 & 19.17 & 34.65 & 15.48 & $92^{\circ}$ & $95^{\circ}$ & $3^{\circ}$ & 525 & 165 & $132^{\circ}$ & $121^{\circ}$ & $11^{\circ}$ & 908,226 & 788,130 \\
\hline 6 . & 840 & 17.78 & 40.65 & 22.46 & $92^{\circ}$ & $96^{\circ}$ & $4^{\circ}$ & 380 & 165 & $132^{\circ}$ & $120^{\circ}$ & $12^{\circ}$ & 990,792 & 760,608 \\
\hline
\end{tabular}


FLOW TEST ON EAST DIGESTER

HEAT EXCHANGE

MEEKS AND DALEY \#66 WELL PUMPED

August 11, 1983 - Mike Lowe

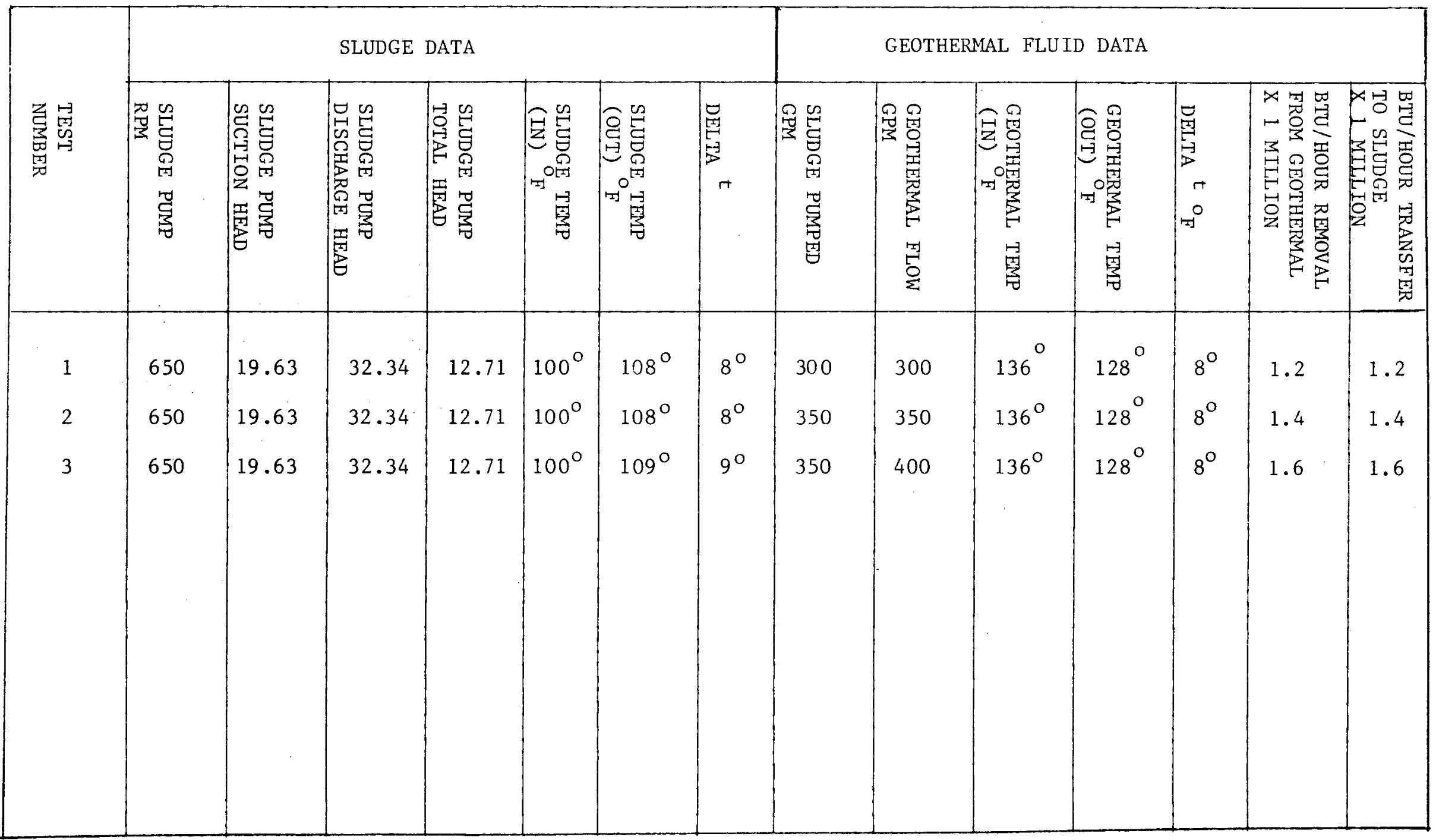


Specifications were developed to furnish and install pumping equipment for the we11. A $500 \mathrm{gpm}$ pump was specified with a depth setting of 100 feet. The specifications required an overall pump efficiency of $70 \%$ with a total dynamic head $(\mathrm{TDH})$ of 120 feet. Informal bids were received and a contract awarded for installation of a Peabody Floway vertical turbine pump with a vertical hollow shaft $25 \mathrm{hp}$ motor. The column assembly is 100 feet with a three stage 10 DOL Peabody Floway bowl assembly.

\subsubsection{Disposal of Geothermal Fluid.}

The method for disposal of the geothermal fluids after use was a determination that had to be made after the quality of the resource was known. Water chemical quality samples taken from Meeks and Daley 非6 We1l, displayed on Table 6, were submitted to John Carollo Engineers to determine if the geothermal fluid could be safely added to the plant tertiary treated effluent without violating established discharge standards. The analysis concluded that a $5: 1$ dilution of geothermal water with treated effluent would make the geothermal water suitable for irrigation. The major chemical constituents in the geothermal water that prevent direct irrigation use are sodium, chloride and boron. Blending the geothermal water with the treated tertiary effluent reduce the constituents to within acceptable levels.

Based on the results of the analysis, the method of discharge selected was to install a six inch pipeline from the heat exchanger to the tertiary reservoir and utilize the stripped geothermal water for in-plant use. The Wastewater Treatment Plant utilizes tertiary water for irrigation, washdown water, and engine cooling water. 


$$
5 \text { - PROJECT COST SUMMARY AND CONCLUSION }
$$

Total project costs incurred are $\$ 508,600$. The costs include resource confirmation and development, purchase and installation of transmission and distribution facilities, retrofit of heat exchangers to utilize geothermal energy, and system testing. The State of California's portion of the costs is $\$ 390,600$, representing $76.8 \%$ of the total project costs. Table 9 presents a summary of project costs.

\subsection{Projected Natural Gas Savings.}

The objective of this project was to utilize low-temperature geothermal energy to provide heat for primary anaerobic digesters at the San Bernardino Wastewater Treatment Plant. Peak heating demand for one digester is 1.5 million Btu's per hour. The annual average heat requirement is 500,000 Btu's per hour. The average annual heat hour requirement is used to determine the offset of natural gas usage.

Based upon heating requirement for one full year, the natural gas offset is determined as follows for one digester:

$500,000 \mathrm{Btu} / \mathrm{Hr} \div 100,000 \mathrm{Btu}$ 's per therm $\mathrm{X} 8760$ hours per year

$\div 80 \%$ efficiency of boiler $=54,750$ therms of natural gas/year.

By 1986, two digesters will be heated with geothermal energy and the natural gas offset will be 109,500 therms per year. Capability will be available to heat by geothermal energy three of four digesters resulting in savings of 164,250 therms of natural gas per year.

\subsection{Cost Comparison of Geothermal Energy to Natural Gas.}

The direct cost of geothermal energy is substantially lower than the cost of natural gas. The cost of maintenance and repair has not been included for 


\author{
TABLE 9 \\ SUMMARY OF PROJECT COSTS \\ FOR DIRECT USE OF GEOTHERMAL ENERGY \\ AT THE SAN BERNARDINO WASTEWATER TREATMENT PLANT
}

1. Resource Confirmation and Development:

(a) Resource Confirmation:

Development of drilling program,

drilling and logging of four (4)

thermal gradient wells.

$\$ 266,337.00$

(b) Resource Development:

Acquisition of Meeks and Daley

\#66 We11 and reequipping of

we11.

$62,654.00 \quad \$ 328,991.00$

2. Purchase and installation of transmission

facilities, retrofit of heat exchanger

$176,724.00$

3. Testing of system and reports to the

California Energy Commission

$2,885.00$

TOTAL PROJECT COSTS..................... \$508,600.00 
either the geothermal facilities or the natural gas boiler system. If such a comparison were to be made, however, the geothermal system would be a less expensive system to maintain.

Cost per therm of usable geothermal energy is based upon the following:

- Power costs to deliver one (1) acre foot of water: $1.023 \mathrm{X}$ 105 feet $\mathrm{TDH} X \$ .07$ per $\mathrm{KWH} \div 70 \%$ efficiency of pump $=\$ 10.74$ per acre foot. This is a conservative calculation which assures 100 percent use of the well pump. In fact, the natural artesian head is adequate for one digester for four months out of the year.

- Therms per acre foot of geothermal water: 43,560 ft. ${ }^{3}$ (acre foot of water) $\times 62.4$ pounds per ft. ${ }^{3} \times 14^{\circ} \mathrm{F}(\Delta t) \div 100,000 \mathrm{Btu}$ 's per therm $=380.53$ therms per acre foot. This $\Delta^{t}$ is based upon average use. In fact, the usable heat, as shown on Table 7, can be as high as $17^{\circ} \mathrm{F}$.

- Power cost per therm: $\$ 10.74 \div 380.53$ therms per acre foot $=\$ .0282$ per therm.

- Amortization of facilities based upon 43,800 therms per year: \$. 20 per therm. Amortized cost per therm is strictly straightline depreciation costs over the useful life of the facilities to include wells, well pumps, pipelines, and appurtenant facilities. The useful life of the components are: pumping equipment - 10 years; pipeline - 35 years; well - 20 years.

- Total cost per therm: $\$ .0282 \$ .0395$ (power cost) $+\$ .20$ (amortization cost $)=\$ .2282$.

The current cost of natural gas from the Southern California Gas Company is $\$ .72$ per therm, or $315 \%$ higher than the cost per usable therm of geothermal 
energy. If electrical and natural gas costs escalate at the same rate, the cost of geothermal energy becomes even more cost effective, since the power required to produce the geothermal heat represents a small portion of the total cost. From other studies, however, it is likely that natural gas prices will escalate faster than electrical prices.

The total therms required to heat the digester with geothermal energy are less than the therms of natural gas due to the operating losses of the boiler at $80 \%$ efficiency. Based upon an average annual hourly requirement of 500,000 Btu's per hour per digester, it will require 54,750 therms of natural gas to provide the equivalent heat of 43,800 therms of geothermal direct use energy.

The use of geothermal energy to provide the annual heat requirements for one digester offsets the cost of $\$ 39,420$ of natural gas based upon today's cost, and results in a cost savings of $\$ 29,425$. By 1986 , additional geothermal. energy will be used to heat at least one additional anaerobic digester, and the cost savings will increase to $\$ 58,850$ at 1983 prices. If natural gas costs rise as projected, the savings will increase significantly.

With two digesters being heated by geothermal energy, the simple pay back is 8.6 years for the total project costs. The pay back period will be reduced as natural gas prices continue to increase.

\subsection{Conclusions.}

The utilization of low temperature geothermal energy at the San Bernardino Wastewater Treatment Plant provides a working model to demonstrate the efficiency and effectiveness of the use of this renewable energy resource.

The resource confirmation segment of this project provides sufficient data showing a large geothermal resource that, with proper management, can be utilized for a long period of time. 
The results obtained from the project provide impetus for more and varied uses of low temperature geothermal energy with the San Bernardino area. The knowledge gained through this project will be invaluable in the next step, the creation of a geothermal district heating system, which will get underway in September, 1983. 
APPENDIX A 


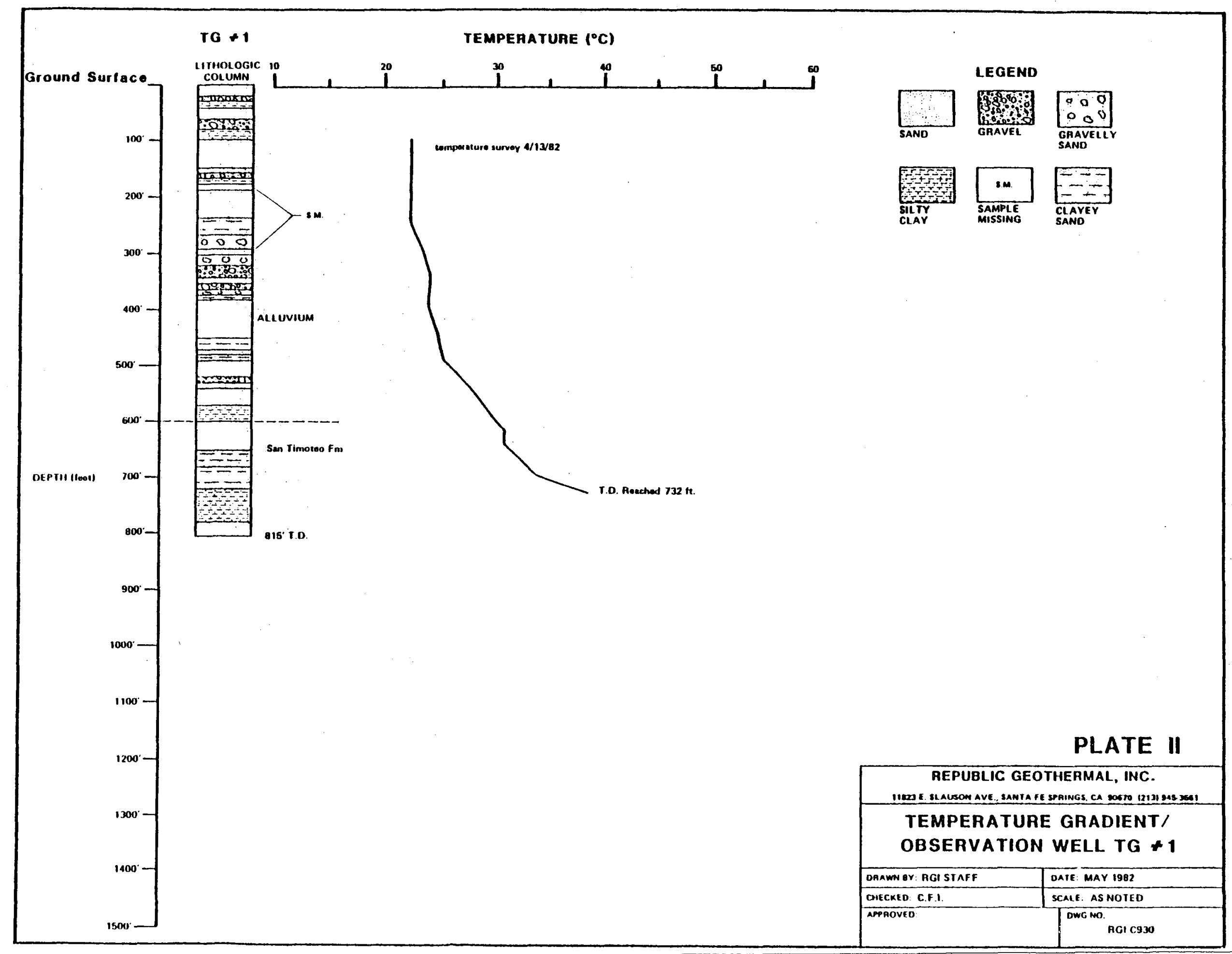




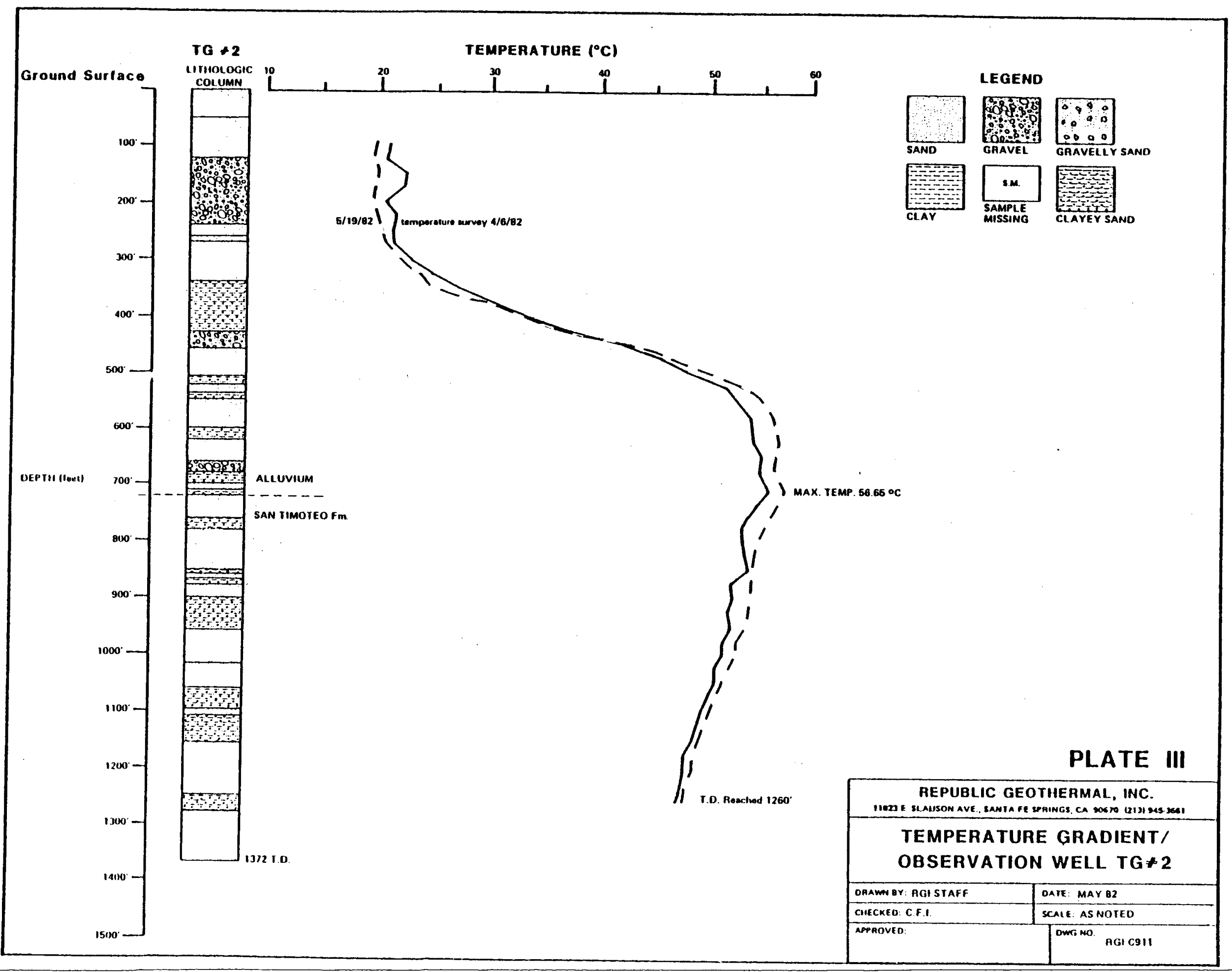




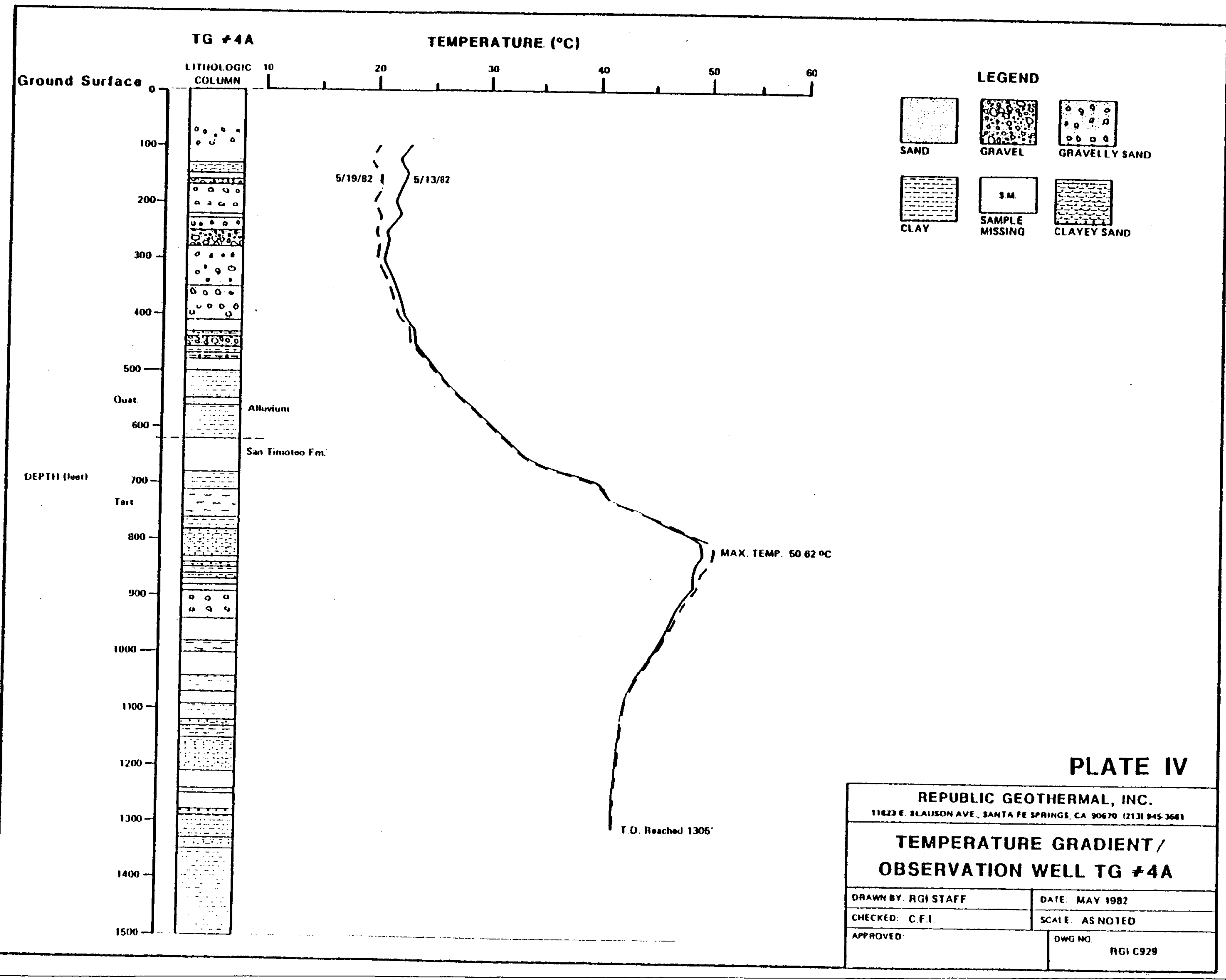




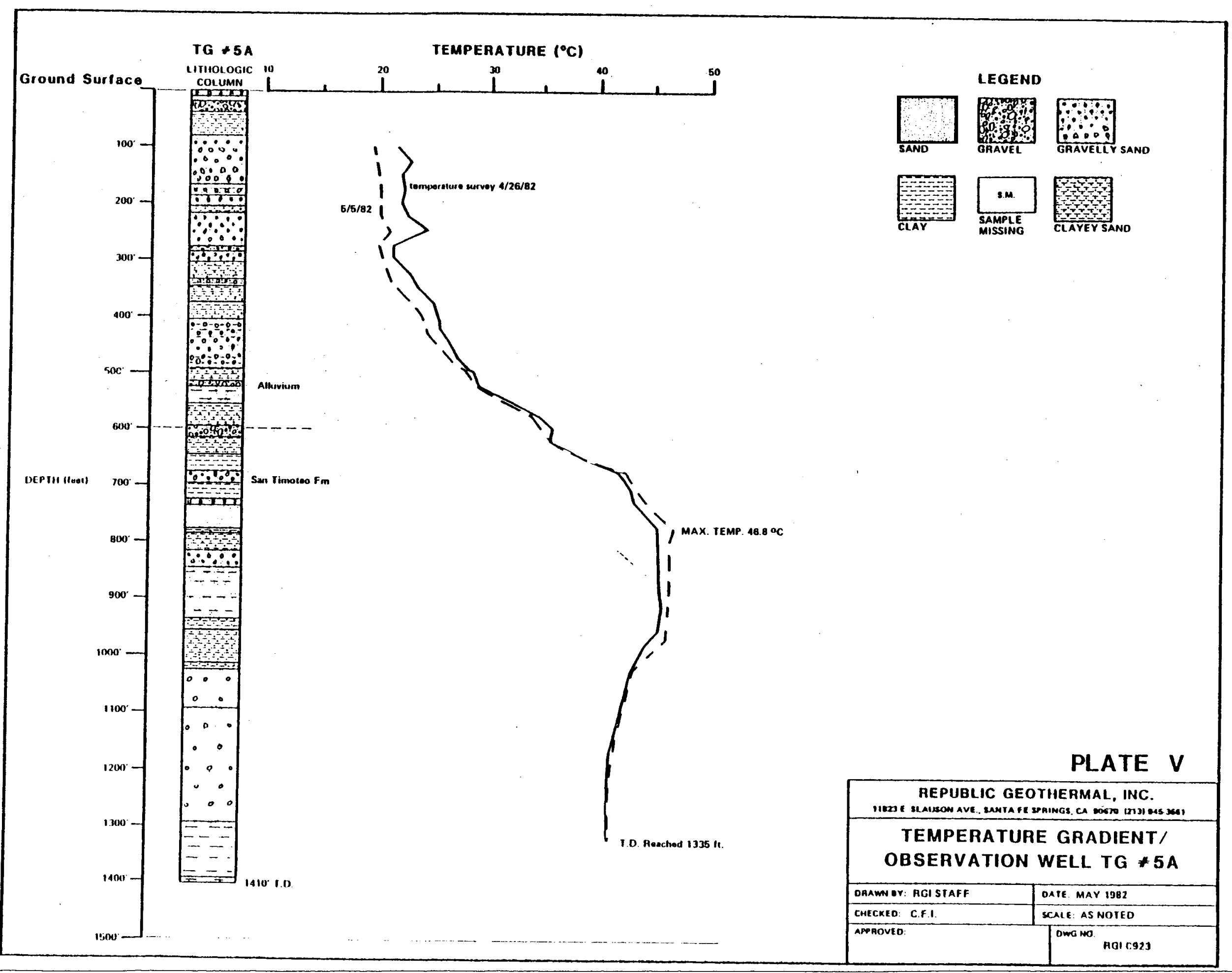




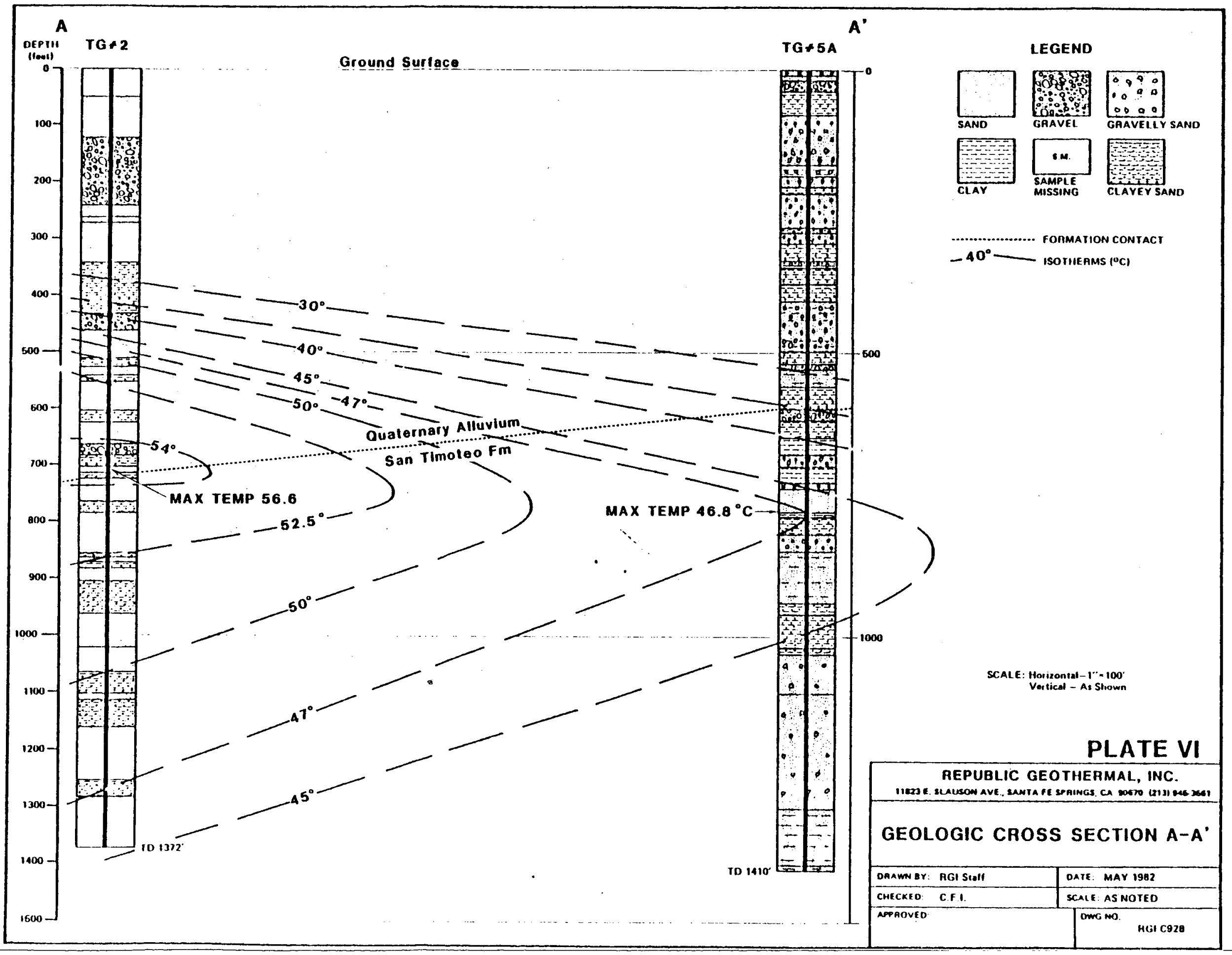







APPENDIX B 


\section{REPUBLIC GEOTHERMAL. INC.}

I1823 EAST SLAUSON AVENUE SUITE ONE

sANTA IF SPRINGS, CALFOANIA DOE70

(213) 9as 3081

Apriz 30, 1982

Mr. Joseph $F$. Stejskal

San Bernardino Municipal Water Department P.O. Box 710

San Bernardino, California 92403

Dear Joe:

Enclosed is a lithologic sumary of Well TG-1 with Republic's preliminary geologic interpretations therefrom.

This hole and all of the others will be reevaluated after equilibrated thermal gradient data have been acquired and assessed.

Please call if you have any questions-

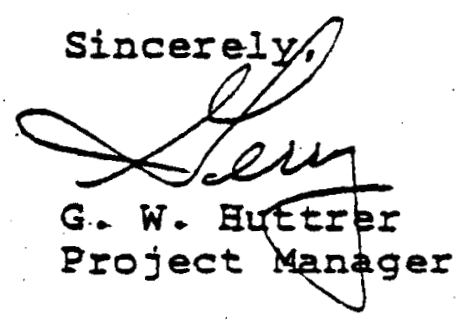

GWE : s jo

Enclosure

cc: E. W. Wellbaum

D. A. Campbell

C. F. Isselharat

P. P. Parmentier

R. E. Yarter 


\title{
REPUBLIC GEOTHERMAL, INC.
}

\author{
MEMORANDUM
}

TO: G. W. Buttrer

FROM: $\quad$ P. P. Parmentier Pfl

April 27, 1982

SUBJECT: Lithologic Summary of well TG-I with Preliminary Geologic Interpretation

\section{Iithology}

The lithology of the formations encountered in the San Bernardino Municipal Water District (SBMWD) well TG-1 was determined by examination of the drill cuttings collected at 10- foot intervals.

In well TG-2, electric logs were used to further define the interpreted lithology; however, in TG-I no self-potential or resistivity log could be obtained in the open hole because of the sloughing of the rock formations. A gamma ray log and a preliminary temperature survey were eventually run in the cased hole, and the results of these surveys are described below.

The formations encountered in TG-1 were basically similar to the rocks encountered in TG-2, consisting of alternating layers of silty clay, medium to very coarse sands, and medium to coarse gravel beds. The detailed description of the lithologic units (Appendix A) and the lithologic column (Figure 1) show that sediments in the upper 610 feet are intercalated gray to pink, medium to coarse sands (mostly granitic and lithic fragments), gravel beds (usually 10 to 20 feet thick), and silty clays 10 to 20 feet thick.

The formations encountered below 610 feet consist of dark gray, medium to coarse sands (locally fairly rich in clay), and one thick, silty clay layer. The different sand layers below 610 feet display remarkable homogenous lithology and grain size. Discrete horizons are up to 50 feet thick, with one clay zone $(730$ to 790 feet) that appears to be about 60 feet thick. 
Memorancium to G. W. Buttrer

April 27, 1982

Paqe 2

Preliminary Interpretation and Comparison with the Lithology of TG-2

As in TG-2, all the formations encountered in TG-1 appear to be of sedimentary origin. The formations above a depth of 610 Eeet in TG-1 are interpreted to be Quaternary alluvium deposits. The formations below this depth are tentatively assigned to the Tertiary San Timoteo Formation, similar to those found in TG-2 below 720 feet. The Quaternary formations in TG-1 appear to contain fewer clay layers and to be somewhat thinner than in TG-2. This characteristic could be significant in the control of qround-water circulation. The formation below 610 feet in TG- 1 greatly resembles that encountered below 720 feet in TG- 2 . The 110-foot discrepancy of the elevation of the Quaternary/Tertiary boundary between the two wells will have to be considered when developing an interpretation of the structural role of the Loma Iinda fault. At this staqe, however, additional data are needed to ascertain the qeometric, three-dimension confiquration of the Loma Iinda fault. It is anticipated that these data will be acquired by drilling the next two thermal gradient wells.

Gamma Ray Logaina of TG-1

A gamma zay log was run to a depth of 737 teet in the cased portion of TG-I on April 13, 1982. The amplitude of the recorded signals was fairly low, probably due to the thick cement zone which impeded the reception of the qamma ray signals. The observed variations in the gamma ray signature were confirmed by several zepetitive runs, and the log will be tentatively interpreted atter a similar gamma $r a y$ Iog is Iun in TG-2, in which good self-potential, resistivity, lithologic, and temperature logs are available.

Preliminary Temperature Survey

A preliminary temperature survey was run to a depth of approximately 725 feet. Although the measured temperatures most certainly do not represent equilibrated values, this preliminary survey shows that the temperature seems to increase in the Tertiary rock formations, and this suggests that the Tertiary/quaternary stratigraphic boundary does not play aydrologic role as important in TG-1 as observed in TG-2.

The final measurement of the temperature in TG-1 will show equilibrated temperature values. The data will contribute to interpretation of the geometric coneiquration of the loma Linda fault and of its bydrologic significance.

$P P P:$ sjo

Attachment 
Appendix A

0-20 feet: Pink, medium sand, well-sorted, with subrounded fragments of mostly granitic origin.

20-30 feet: Pink, coarse gravel.

30-40 feet: Gray, silty clay.

40-60 feet: Pink, medium sand, moderately sorted, with 5\% gravel-size grains and 58 mafic grains.

60-80 feet: Very coarse gravel with subrounded lithic rock Eragments.

80-100 feet: Gray, silty clay.

100-150 feet: Gray, medium sand, with 208 mafic subangular grains, well-sorted, and locally 5 g gravel-size grains.

150-160 Eeet: Coarse sand, similar in lithologic composition to that logged between 100-150 feet.

160-170 feet: Gray, coarse gravel with subrounded lithic Eragments.

170-180 feet: Gray, silty clay.

180-190 feet: Sample missing.

190-240 feet: Grayish-pink, medium sand, well-sorted, locally with subangular, gravel-size, lithic Eragments, and traces of clay.

240-270 feet: Clayey, medium to coarse sand, well-sorted.

270-300 feet: Pink, gravelly medium sand, well-sorted.

300-310 feet: Sample missing.

310-330 feet: Pink, gravelly medium sand, well-sorted.

330-350 feet: Medium to coarse gravel, poorly sorted, with mostly granitic lithic fragments.

350-360 feet: Pink, medium sand, well-sorted.

360-370 feet: Sandy, coarse gravel, similar to 330-350 feet.

370-380 feet: Gravelly, medium sand.

380-390 feet: Clayey, medium sand. 
390-460 feet: Pink, medium sand, poorly sorted, locally with up to 10 gravel-size lithic fragments.

460-480 feet: Clayey, coarse sand, poorly sorted, with gravel-size angular lithic fragments.

480-490 feet: Well-sorted medium sand.

490-500 feet: Clayey, medium to coarse sand.

500-530 feet: Pink, medium sand, moderately sorted, with $5 \%$ mafic grains.

530-540 feet: Medium gravel with subangular lithic fragments.

540-550 feet: Well-sorted medium sand.

550-580 feet: Clayey, pink, medium sand, moderately sorted.

580-610 feet: Gray, silty clay.

610-660 feet: Dark gray, coarse sand, slightly clayey, moderately sorted with subangular grains, dominantly mafic grains.

660-690 feet: Same coarse sand as 610-660 feet, with more clay and dominant mafic grains.

690-730 feet: Dark gray, clayey, medium sand, well-sorted, with predominantly mafic grains.

730-770 feet: Dark gray, silty clay.

770-790 feet: Brown, silty clay

790-820 feet: Dark gray, medium sand, well-sorted, with subangular lithic Eragments of granitic and schistose composition. 
FIGURE 1

SAN BERNARDINO MUNICIPAL WATER DISTRICT

TEMPERATURE GRADIENTIOBSERVATION WELL TG \# 1

LITHOLOGIC COLUMN

LEGEND

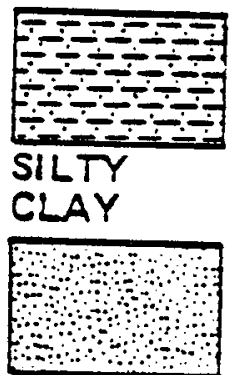

SAND

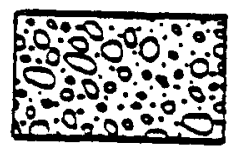

GRAVEL

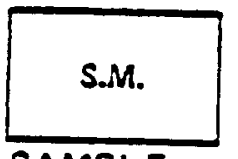

SAMPLE MISSING
FEET
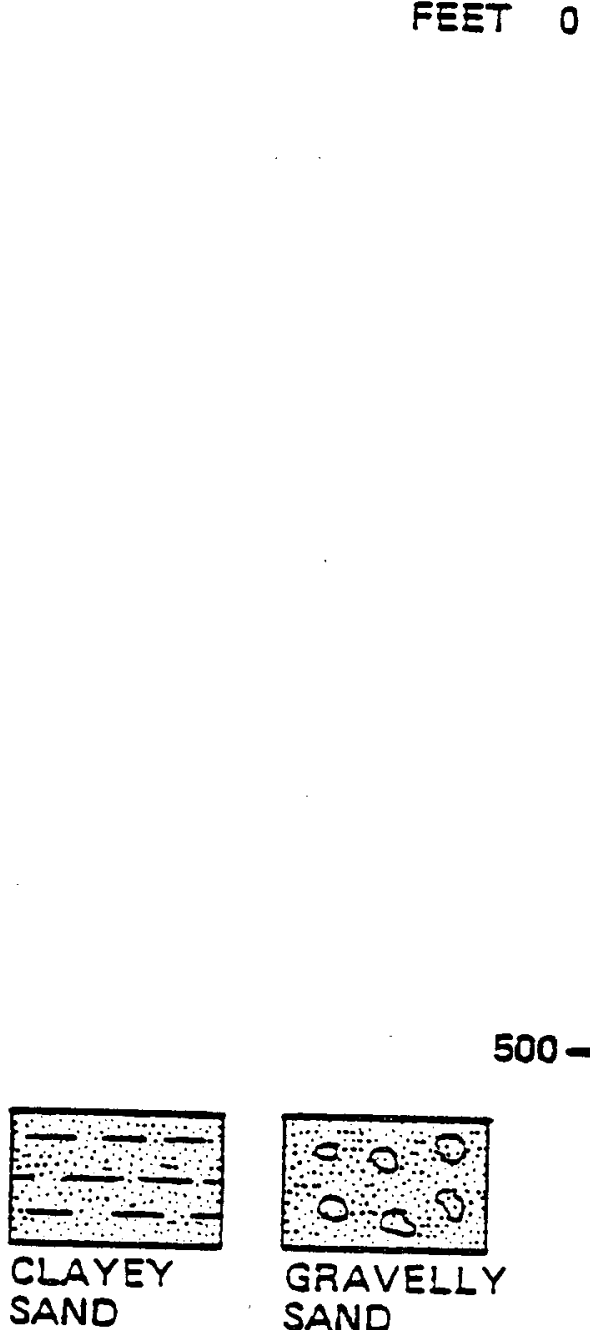

GRAVELLY SAND
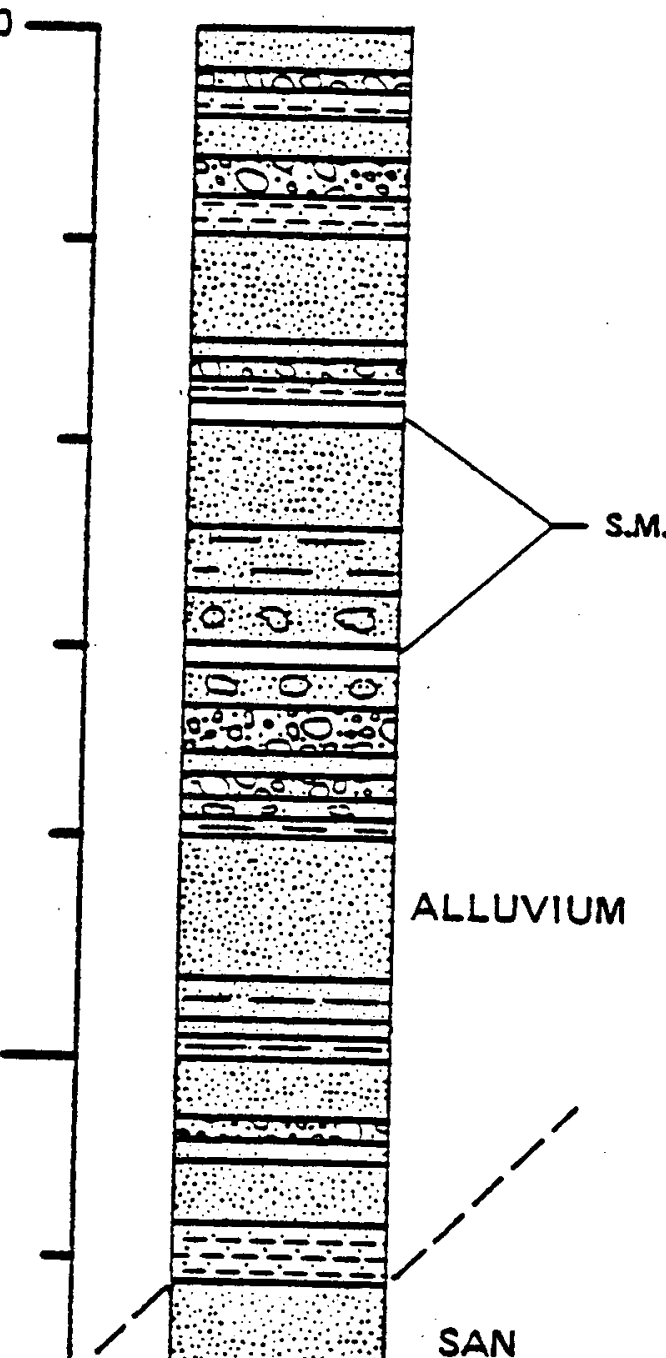

ALLUVIUM
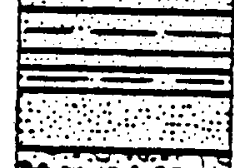

a

$\div-\div-\div$
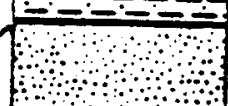

SAN

TIMOTEO F.M.

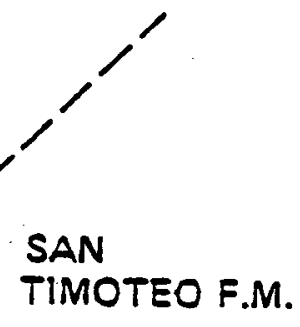

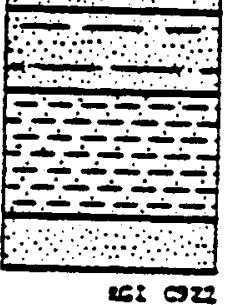

815' T.D. 
APPENDIX C

- 
REPUBLIC GEOTHERMAL, INC.

11823 EAST SLAUSON AVENUE

SANTA FE SPRINGS. CALIFORNIA DOE70

Tux .010 .586 .1696

(213) 9453661

April 5, 1982

Mr. Joseph Stejskal

City of San Bernardino Water Department

300 North D Street

San Bernardino, California 92401

Dear Joe:

Attached, for your information, is a memorandum related to our preliminary interpretation of data from. TG-2. please call if you have any questions.

GWE : sjo

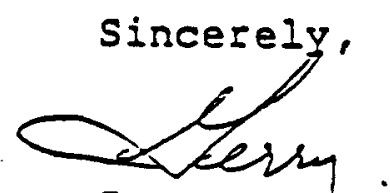

G. W. Etrier

Project panager

Attachments 


\title{
REPUBLIC GEOTHERMAL, INC.
}

\author{
MEMORANDUM
}

TO:

G. W. Buttrer

April 5,1982

FROM:

P. P. Parmentier

Pal P. Pamere

SUBJECT: Lithologic summary of well TG-2 with Preliminary Geologic Interpretation

\section{Iithology}

The lithology of the formations encountered in the San Bernardino Municipal Water District (SBMWD) well TG-2 were determined by examination of the drill cuttings collected at 10-foot intervals. The lithologic sequence is further defined by the open-hole electric logs which will be described later.

The formations encountered in TG-2 consist principally of successive alternating layers of silty clay, medium to very coarse sand, and medium to coarse gravel beds. The detailed description of the lithologic units (Appendix A) and the lithologic column (Figure i) show that sediments in the upper 700 feet consist of alternating silty clay zones, locally fairly thick at depths of 340-430 feet, $600-620$ feet, and 680-700 feet; medium to coarse sand zones with grains of diverse lithologic origin and gravels, locally fairly thick at depths of $120-240$ feet, 430 to 460 feet, and 660 to 680 feet. The formations encountered below 700 feet consist of intercalated very coarse sands and clay layers. The different sand layers display remarkably homogeneous lithology and grain size, with thicknesses up to 90 feet, and the clay zones appear to be up to 60 feet thick.

\section{Preliminary Interpretation}

All of the formations encountered in IG-2 appear to be of sedimentary origin. The formations above 720 feet are interpreted to be Quaternary alluvium deposits. The formations below this depth are tentatively assigned to the san Timoteo formation of Tertiary to Quaternary age, the nearest outcrops of which are approximately three miles south of TG-2. 
Memorandum to $G$. W. Buttrer

April 5, 1982

Page 2

The San mimoteo rocks seen in the outcrop comprise layers of mostly unconsolidated sand and gravel, a few inches to several feet thick, with local silt and clay interbeds. In outcrops located near the San Jacinto fault, these formations dip steeply in tight folds and fault blocks. The homogenity of the ithology observed from about 700 feet to total depth in TG-2 suggests that the formations may have been penetrated diagonally, showing apparent bed thicknesses that are much greater than actual thickness values. It is possible that sharp bending of these rocks near the Loma Iinda fault zone may be partially responsible for the "aquatard" effect of the fault zone.

The unconformable contact between the upper, more recent sediments and the lower San Timoteo formation has tentatively been set at about 720 feet. The effect of this boundary on the local hydrothermal circulation may later be observed in the temperature profile of the well.

Electric Logging of TG-2

Two simultaneous electric logs (Self Potential and Resistivity) were run in TG-2 on March 30,1982 , before cementing of the $2-3 / 8^{\text {" }}$ tubing. Due to time constraints, no gamma ray log was run, but the SP and resistivity log will provide sufficient information for correlation with other wells and for future perforation of this well.

Although the SP log does not have strong character and appears locally to be "reversed," it reflects adequately the results of the resistivity log, which defines fairly precisely the alternating clay, sand, and gravel layers. The lithology that can be interpreted from the electrical log corresponds fairly well with the Iithology described from the cuttings, and it additionally defines some minor lithologic units within the broader lithologic layers described from the geology.

The SP variations observed below a depth of about 730 feet appear to be less distinct than the those observed at shallower depths. This could be due to the fact that the san Timoteo formation lithologic boundaries may be dipping at fairly high angles, thereby minimizing changes in the signature of the sp curve in that unit. Our belief that a stratigraphic boundary exists at approximately 700 feet is supported by this change in character in the electric logs.

PPP: sjo

Attachment 


\begin{tabular}{|c|c|c|}
\hline $0-50$ & feet & $\begin{array}{l}\text { Medium-grained sand with angular grains } \\
\text { of quartz, feldspars, and lithic } \\
\text { fragments. }\end{array}$ \\
\hline $50-120$ & Eeet & $\begin{array}{l}\text { Coarse sand with varying proportion of } \\
\text { medium-grained sand with similar grain } \\
\text { composition as } 0-50 \text { foot depth interval. }\end{array}$ \\
\hline $120-240$ & feet & $\begin{array}{l}\text { Gravel with varying proportion of } \\
\text { coarse sand, with angular to subangular } \\
\text { grains of feldspars, quartz, and mafic } \\
\text { lithic fragments. }\end{array}$ \\
\hline $240-270$ & feet & $\begin{array}{l}\text { Very coarse sand with both lithic } \\
\text { Eragments and mineral grains. }\end{array}$ \\
\hline $270-280$ & Eeet & $\begin{array}{l}\text { Medium-grained sand with minor amounts } \\
\text { of clay. }\end{array}$ \\
\hline $280-340$ & feet & $\begin{array}{l}\text { Coarse sand with various amounts of } \\
\text { clay and gravel-size grains of granitic } \\
\text { mineral composition and lithic } \\
\text { fragments. }\end{array}$ \\
\hline $340-430$ & feet & $\begin{array}{l}\text { Gray, silty clay of fairly constant } \\
\text { lithology. }\end{array}$ \\
\hline $430-460$ & feet & $\begin{array}{l}\text { Gravel, with minor amounts of sand and } \\
\text { clay. }\end{array}$ \\
\hline $460-510$ & feet & $\begin{array}{l}\text { Very coarse sand with minor clay, } \\
\text { similar to } 280-340 \text { feet. }\end{array}$ \\
\hline $520-520$ & Eeet & Gray, silty clay \\
\hline $520-540$ & Eeet & $\begin{array}{l}\text { Medium-grained sand, similar to } \\
\text { interval } 280-340 \text { feet. }\end{array}$ \\
\hline $540-550$ & feet & Brown, silty clay \\
\hline $550-600$ & Eeet & $\begin{array}{l}\text { Very coarse sand with varying amounts } \\
\text { of gravel and clay. }\end{array}$ \\
\hline $600-620$ & feet & Brown, silty clay. \\
\hline $620-660$ & feet & $\begin{array}{l}\text { Medium-grained sand with approximately } \\
70 \% \text { mafic grains. }\end{array}$ \\
\hline $660-680$ & feet & $\begin{array}{l}\text { Coarse gravel consisting of lithic } \\
\text { Eragments. }\end{array}$ \\
\hline
\end{tabular}




\begin{tabular}{|c|c|c|}
\hline $680-700$ & feet & Brown, silty clay. \\
\hline $700-710$ & feet & $\begin{array}{l}\text { Medium-grained sand, similar to } \\
\text { intervai } 620-660 \text { feet. }\end{array}$ \\
\hline $710-720$ & Eeet & Brown, silty clay. \\
\hline $720-760$ & feet & $\begin{array}{l}\text { Medium-grained sand with various } \\
\text { amounts of clay and minor amounts of } \\
\text { white chalk grains. }\end{array}$ \\
\hline $760-780$ & feet & Dark gray, silty clay. \\
\hline $780-850$ & Eeet & very coarse sand with 5 gravel. \\
\hline $850-860$ & feet & Brown, silty clay. \\
\hline $860-870$ & feet & $\begin{array}{l}\text { Very coarse sand, similar to interval } \\
720-760 \text { feet. }\end{array}$ \\
\hline $870-880$ & feet & Brown, silty clay. \\
\hline $880-900$ & feet & $\begin{array}{l}\text { Very coarse sand, similar to interval } \\
720-760 \text { feet. }\end{array}$ \\
\hline $900-960$ & feet & Brownish gray, silty clay. \\
\hline $960-1030$ & feet & $\begin{array}{l}\text { Very coarse sand with large proportion } \\
(25 \%) \text { of pink R-feldspar grains. }\end{array}$ \\
\hline $1030-1060$ & feet & $\begin{array}{l}\text { Very coarse sand with numerous mafic } \\
\text { grains and minor amounts of biotite. }\end{array}$ \\
\hline $1060-1100$ & feet & Gray, silty clay. \\
\hline $1100-1110$ & feet & $\begin{array}{l}\text { Very coarse sand, similar to interval } \\
1030-1060 \text { feet. }\end{array}$ \\
\hline $1110-1160$ & Eeet & Brown to dark gray, silty clay. \\
\hline $1160-1250$ & Eeet & $\begin{array}{l}\text { Very coarse sand with subangular grains } \\
\text { having } 108 \text { pink grains, } 208 \text { white } \\
\text { grains, } 208 \text { greenish gray grains, } 208 \\
\text { gray grains, and los black, mafic } \\
\text { grains. }\end{array}$ \\
\hline $1250-1280$ & feet & Dark gray, silty clay. \\
\hline $1280-1370$ & feet & $\begin{array}{l}\text { Very coarse sand, same as } 1160-1250 \\
\text { feet. }\end{array}$ \\
\hline
\end{tabular}


FIGURE 1

SAN BERNARDINO

MUNICIPAL WATER DISTRICT

TEMPERATURE GRADIENT/OBSERVATION WELL TG \#2

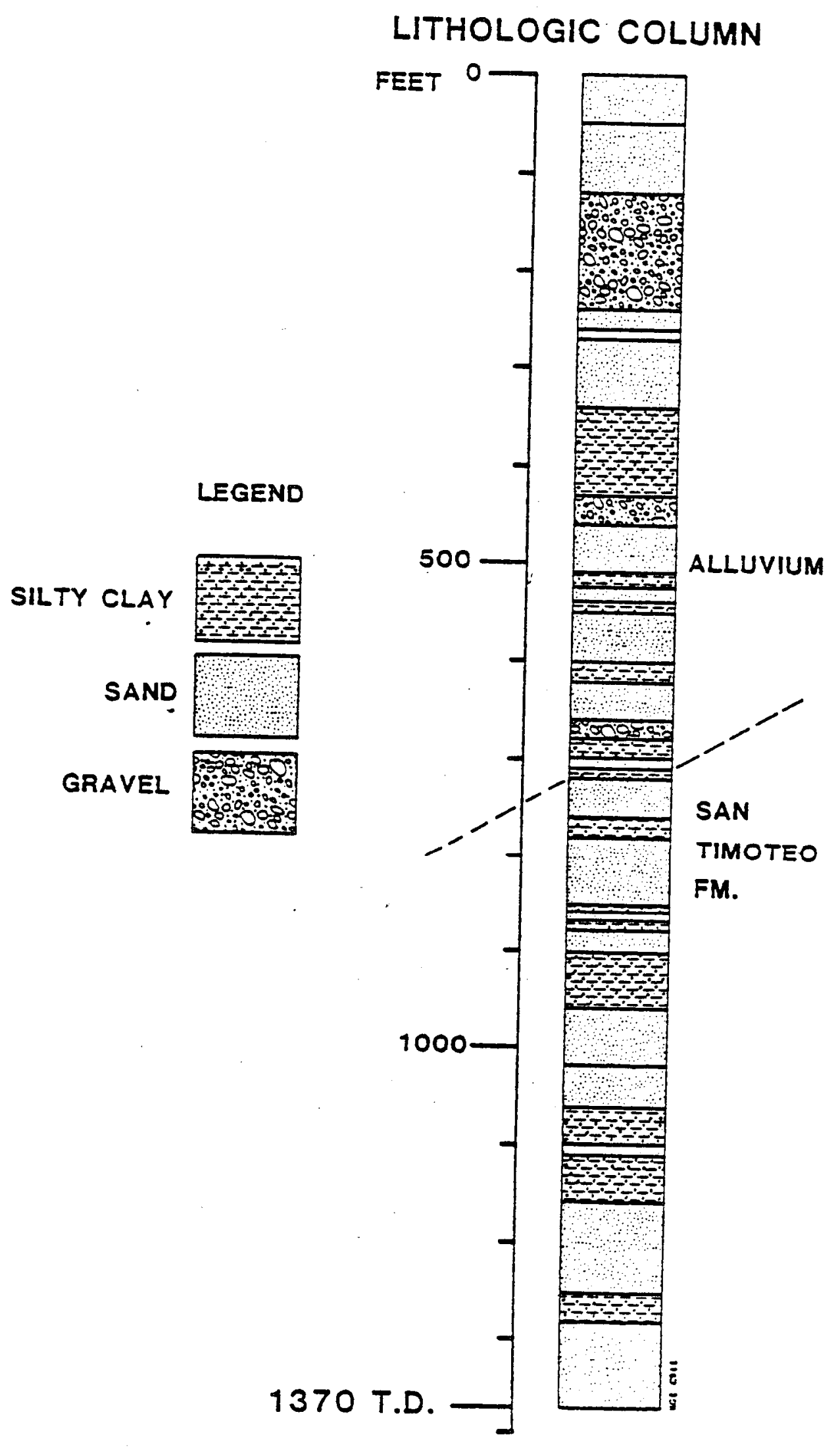


APPENDIX D 
REPUBLIC GEOTHERMAL, INC.

11823 EAST SLAUSON AVENUE

SANTA FE SPRINGS. CALIFORNIA DO670

(213) 9453661

May 21, 1982

Mr. Joseph F. Stejskal

San Bernardino Municipal Water Department

P.O. Box 710

San Bernardino, California 92403

Dear Joe:

Enclosed is our summary report concerning TG-4A. I think that the document is self-explanatory, but don't hesitate to call if you have questions.

We are currently writing a report that discusses all of the thermal gradient wells, their geology, their thermal aspects, and the overall scenario. We will, in this report, be recommending, prioritizing, and justifying one or more alternative sites for the production well.

GWE : 5 jo

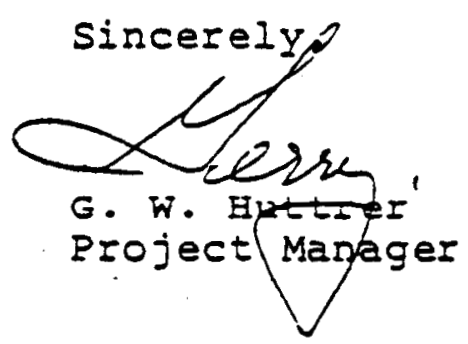

Enclosure

cc: E. W. Wellbaum

J. R. Stites

D. A. Campbell

C. F. Isselharat

R. E. Yarter 
REPUBLIC GEOTHERMAL, INC.

\author{
$M E M O R A N D U M$
}

TO: G. W. Huttrer

May 20, 1982

FROM: $\quad$ C.. F. Isselhardt CZ.d.

SUBJECT: Iithologic and Temperature Data Summary of Gradient Hole TG-4A.

\title{
Iithology
}

The nature of the sediment; penetrated by well TG-4A was determined by visual examination of the drill cuttings collected at 10-foot intervals in a manner similar to that applied to wells TG-2, TG-I, and TG-5A. Both gamma ray and SP-resistivity logs were run in the open hole interval (230-1,500 feet) to enhance lithologic interpretation.

The lithology encountered is basically the same as that found in TG-1, TG-2, and TG-5A and is composed predominantly of intercalated becs of unconsolidated coarse to very coarse-grained sands and pebbly sands, medium-grained gravels, and sandy to silty clays (Figure 1). In this hole, however, the gamma ray and SP logs show that a few sands are up to 45 feet thick. The lithology, as interpreted from cuttings, does not always agree well with interpretations made from electric logs, especially in the bottom 150 feet of the hole where the cuttings' samples (Appendix A - Sample Descriptions) are all clay and where the logs indicate sand predominating. The probable explanation for this discrepancy is that the cuttings' samples were not taken at the proper time.

The contact between the Quaternary aliuvium and the Fertiary San Timoteo Formation is placed at 620 feet based on the marked increase in dark iithic fragments of schist and gneiss in the sands and gravels at that point. The E-logs, however, show no noticeable change in this area. As in the other wells, the sands of the san Timoteo Formation appear to be better sorted than those in the Quaternary alluvium. On the electric logs, particularly the SP, there appears to be more sand between 740 feet and 1,500 feet than in the interval from the ground surface to 740 feet. 
Memorandum to $G$. W. Huttrer

May 20, 1982

Page 2

Preliminary Interpretation and Comparison with other wells

Well TG-4A is the deepest hole drilled to date (1,500 feet). As in the other three holes, the units penetrated are unconsolidated Quaternary alluvial sediments and clays, sands, and gravels assigned to the Tertiary San Timoteo Formation. Although FG-4A is only about 200 feet frol TG-1, the lithologic sequences differ somewhat, reflecting the Santa Ana River channel-type (complexly braided) sedimentary environment.

The structural and temperature cata gleaned from this well have added to our knowledge considerably, but they are puzzling in some respects. Of especial interest is the fact that while the top of the San Timoteo Formation dips generaliy to the west, the maximum temperature isotherms dip to the south-southeast. This may reflect the effect of structural control on the hydrothermal system that apparently cuts across stratigraphic boundaries.

Logging of TG-4A

Well TG-4A was logged with a different instrument than that used in the other wells, and we were, therefore, able to get high quality gamma ray and SP-resistivity logs. These logs provided excellent sand-shale discrimination and show some interesting apparent SP reversals in several portions of the well (particularly the last $200+$ feet). These reversals may, if they are real, be due to changes $i \bar{n}$ water salinity that, in turn, may be related to temperature changes in the ground water.

Preliminary remperature Survey

A preliminary temperature survey was run to a depth of 1,300 feet on May 13, 1982, about six days after completion of the well (Figure 2). The temperature probe was unable to go below 1, 300 feet (tubing was run to 1,495 feet), probably due to residual cement in the tubing.

This temperature profile, though not completely equilibrated, indicates very clearly the convective and maximum temperature zone that extends from about 780 to 875 feet. The top of this zone coincides closely with the top of the aquifer in well mG-5A (775 feet), although it is not as thick and has a higher temperature $\left(49^{\circ} \mathrm{C}\right.$ versus $\left.45^{\circ} \mathrm{C}\right)$. A final temperature survey will be conducted on May 19, 1982, but neither the temperature gradient protile nor the absolute temperatures are expected to change significantly. 
Memorandum to G. W. Huttrer

May 20, 1982

Page 3

The temperatures encountered indicate that this aquifer contains a mixture of thermal $\left( \pm 56^{\circ} \mathrm{C}\right)$ and nonthermal waters similar to those interpreted to exist in TG-5A.

CEI: sjo

Attachments 
FIGURE ,

TG AA STRATIGRAPHIC COLUMN

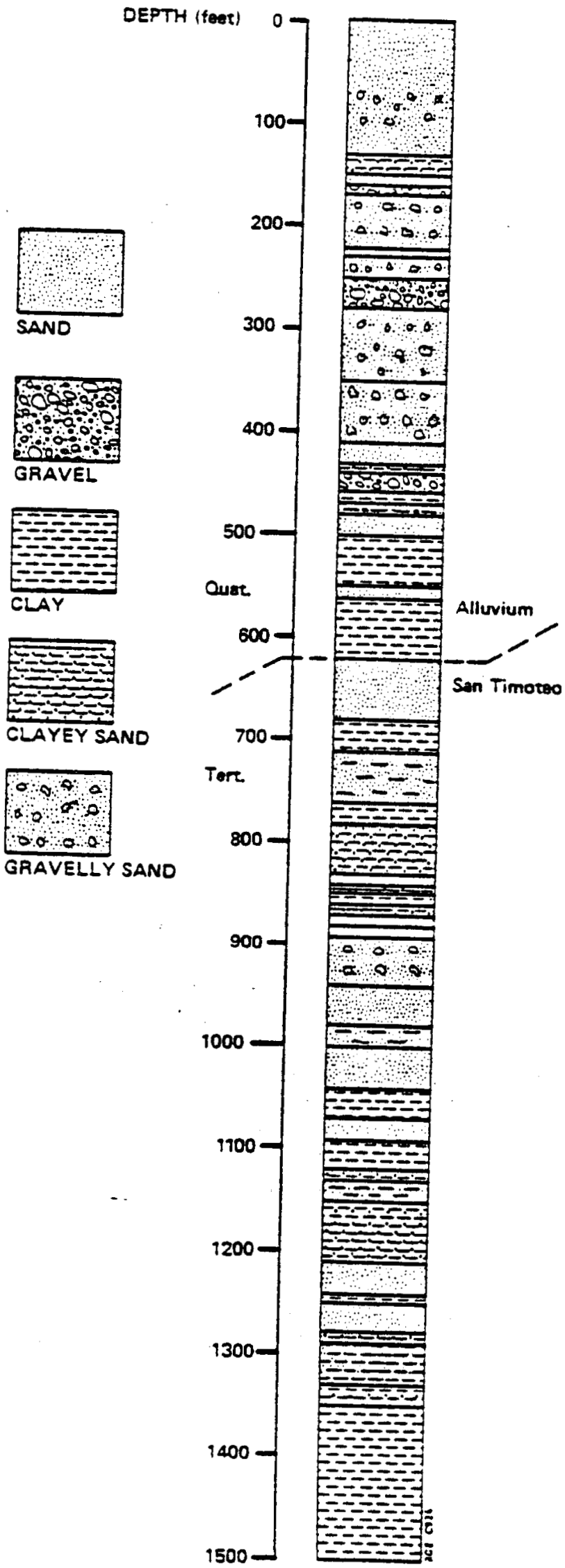


APPENDIX A

WELI TG-4A

SAMPLE DESCRIPTIONS

\begin{tabular}{|c|c|c|}
\hline $0-10$ & feet & $\begin{array}{l}\text { Sand-pink-white-light gray, coarse to very } \\
\text { coarse, angular, unconsolidated, well-sorted, } \\
\text { arkosic, with pink K-feldspars and some dark } \\
\text { gray rock fragments. }\end{array}$ \\
\hline $10-70$ & feet & $\begin{array}{l}\text { Sand-as above, predominantly very coarse- } \\
\text { grained. }\end{array}$ \\
\hline $70-80$ & feet & $\begin{array}{l}\text { Sand-as above, with } 15 \text { g gravel, predominantly } \\
\text { dark gray rock fragments. }\end{array}$ \\
\hline $80-100$ & feet & Sand-as above, with 5-10\% gravel. \\
\hline $100-130$ & feet & $\begin{array}{l}\text { Sand-as above, coarse-grained, well-sorted, } \\
\text { only trace gravel. }\end{array}$ \\
\hline $130-150$ & feet & Clay-mediun gray, soft, with 5 s sand. \\
\hline $150-160$ & feet & $\begin{array}{l}\text { Sand-multicolored, as above, with } 5 \text { g gray clay, } \\
\text { rare gravel. }\end{array}$ \\
\hline $160-170$ & feet & $\begin{array}{l}\text { Gravel-multicolored, as above, angular- } \\
\text { subangular, with log gray clay. }\end{array}$ \\
\hline $170-210$ & feet & $\begin{array}{l}\text { Sand-as above, medium- to coarse-grained, with } \\
208 \text { gravel, no clay. }\end{array}$ \\
\hline $210-220$ & feet & $\begin{array}{l}\text { Sand-as above, coarse to very coarse, with } \\
\text { 15-208 gravel. }\end{array}$ \\
\hline $220-230$ & feet & Sample missing. \\
\hline $230-240$ & Eeet & $\begin{array}{l}\text { Sand-as above, medium- to coarse-grained, with } \\
\text { 15-208 gravel. }\end{array}$ \\
\hline $240-250$ & feet & Sand-as above, with 30 g gravel. \\
\hline $250-280$ & feet & Gravel-well sorted, $1 / 2 "$ diameter, trace sand. \\
\hline $280-350$ & Eeet & $\begin{array}{l}\text { Sand-unconsolicated, multicolored, medium- to } \\
\text { coarse-grained, with } 15-20 \text { \% } 1 / 4 " \text { gravel. }\end{array}$ \\
\hline $350-410$ & feet & $\begin{array}{l}\text { Sand-as above, becoming coarse to very coarse, } \\
\text { with } 30-408 \text { gravel. }\end{array}$ \\
\hline $410-430$ & feet & $\begin{array}{l}\text { Sand-as above, coarse-grained, well-sorted, } \\
\text { angular, with } 5 \text { gr gray clay. }\end{array}$ \\
\hline $430-440$ & feet & $\begin{array}{l}\text { Clay-brownish gray, soft, with } 20 \text { g coarse sand, } \\
\text { as above. }\end{array}$ \\
\hline
\end{tabular}




\begin{tabular}{|c|c|c|}
\hline $440-460$ & Eeet & $\begin{array}{l}\text { Gravel-multicolored, angular, unconsolidated, } \\
\text { with } 20 \% \text { coarse sand. }\end{array}$ \\
\hline $460-470$ & feet & $\begin{array}{l}\text { Clay-light brown, soft, with los coarse sand } \\
\text { and gravel. }\end{array}$ \\
\hline $470-480$ & feet & $\begin{array}{l}\text { Sand-very coarse, with } 10-158 \text { gravel and } 208 \\
\text { clay, as above. }\end{array}$ \\
\hline $480-490$ & feet & Sand-as above, with 58 clay. \\
\hline $490-500$ & feet & $\begin{array}{l}\text { Sand-medium- to coarse-grained, multicolored, } \\
\text { with } 5 \text { gr gravel. }\end{array}$ \\
\hline $500-550$ & feet & Clay-light brown, soft, with trace -5 s sand \\
\hline $550-560$ & feet & $\begin{array}{l}\text { Sand-coarse to very coarse-grained, } \\
\text { well-sorted, multicolored, with pink } \\
\text { k-feldspars, as above, with trace gravel. }\end{array}$ \\
\hline $560-620$ & feet & Clay-light brown, soft, with trace -few \& sand. \\
\hline $620-660$ & Eeet & $\begin{array}{l}\text { Sand-unconsolidated, multicolored but darker } \\
\text { gray overall, marked increase in dark gray rock } \\
\text { fragments (San Fimoteo Formation), medium- } \\
\text { coarse grained, with trace gravel. }\end{array}$ \\
\hline $660-680$ & feet & $\begin{array}{l}\text { Sand-as above, with slight increase in pink } \\
\text { feldspar fragments and trace - } 58 \text { clay. }\end{array}$ \\
\hline $680-710$ & feet & Clay-medium gray, soft, with 5 g sand. \\
\hline $710-760$ & feet & $\begin{array}{l}\text { Clayey sand-multicolored, with abundant dark } \\
\text { gray rock fragments, unconsolidated, coarse to } \\
\text { very coarse, angular sand with } 20-30 \text { of gray clay. }\end{array}$ \\
\hline $760-780$ & feet & Clay-brownish gray, soft, with <5o sand. \\
\hline $780-830$ & feet & $\begin{array}{l}\text { Sandy clay-gray to brown gray, with } 45 \text { s sand, } \\
\text { coarse to very coarse. }\end{array}$ \\
\hline $830-840$ & feet & $\begin{array}{l}\text { Sand-unconsolidated, angular, moderately well- } \\
\text { sorted, coarse to very coarse sand, as above, } \\
\text { with log gray clay. }\end{array}$ \\
\hline $840-850$ & feet & $\begin{array}{l}\text { Sandy clay-brownish gray clay with } 30-40 \% \\
\text { coarse sand. }\end{array}$ \\
\hline $850-860$ & Eeet & Clay-light brown clay with trace sand. \\
\hline $860-870$ & feet & $\begin{array}{l}\text { Sand-coarse to very coarse, unconsolidated, as } \\
\text { above, with 5-10\% brownish gray clay. }\end{array}$ \\
\hline $870-880$ & feet & Sand-as above, no clay. \\
\hline $880-890$ & feet & No sample. \\
\hline
\end{tabular}




\begin{tabular}{|c|c|c|}
\hline $890-940$ & feet & $\begin{array}{l}\text { Pebbly sand-as above, very coarse, with 10-158 } \\
\text { pebbles or fine gravel. }\end{array}$ \\
\hline $940-980$ & feet & $\begin{array}{l}\text { Sand-multicolored, light to dark gray, angular, } \\
\text { coarse to very coarse, well-sorted, as above, } \\
\text { with trace - } 58 \text { gray clay, no pebbles. }\end{array}$ \\
\hline $980-1000$ & feet & $\begin{array}{l}\text { Clayey sand-sand, as above, with 15-20\% gray } \\
\text { clay. }\end{array}$ \\
\hline $1000-1040$ & feet & $\begin{array}{l}\text { Sand-multicolored, as above, no clay, trace } \\
\text { pebbles. }\end{array}$ \\
\hline $1040-1070$ & Eeet & Clay-light brownish gray, soft, with trace sand. \\
\hline $1070-1090$ & Eeet & Sand-as above, well-sorted, with 10-15\& clay. \\
\hline $1090-1120$ & Eeet & Clay-light brownish gray. \\
\hline $1120-1130$ & feet & $\begin{array}{l}\text { Sandy clay-clay as above, with } 208 \text { sand, } \\
\text { coarse, well-sorted, as above. }\end{array}$ \\
\hline $1130-1150$ & feet & $\begin{array}{l}\text { Clayey sand-sand as above, with 20-308 clay, as } \\
\text { above. }\end{array}$ \\
\hline $1150-1210$ & feet & $\begin{array}{l}\text { Sandy clay-light browrish gray soft clay, with } \\
5-10 \% \text { sand, as above, sand increases with depth } \\
\text { up to } 20 \% \text { at } 1180 \text { feet, then decreases to } 5 \% \text { to } \\
\text { I210 feet. }\end{array}$ \\
\hline $1210-1240$ & feet & $\begin{array}{l}\text { Sand-light to dark gray, multicolored, } \\
\text { (abundant dark gray rock fragments) moderately } \\
\text { well-sorted, angular, unconsolidated. }\end{array}$ \\
\hline $1240-1250$ & feet & Clay-brownish gray clay, soft, with 5 o sand. \\
\hline $1250-1280$ & feet & $\begin{array}{l}\text { Sand-predominantly dark gray rock fragments, as } \\
\text { above. }\end{array}$ \\
\hline $1280-1290$ & feet & Sandy clay-as above, with 30 z sand. \\
\hline $1290-1330$ & Eeet & $\begin{array}{l}\text { Clayey sand-sand as above, with } 20-30 \text { gr gray } \\
\text { clay, as above. }\end{array}$ \\
\hline $1330-1350$ & $\begin{array}{l}\text { feet } \\
\text { T.D. }\end{array}$ & $\begin{array}{l}\text { Sandy clay-gray clay, as above, with } 208 \text { sand. } \\
\text { clay-as above, gray to brownish gray, with } 58 \\
\text { sand. }\end{array}$ \\
\hline
\end{tabular}


APPENDIX E 
REPUBLIC GEOTHERMAL, INC.

19823 EAST SLAUSON AVENUE SUTTE ONE

SANTA FE SPRINGS. CALJFORNIA DOETO

(213) 9453661

May 5, 1982

Mr. Joseph F. StejskaI.

San Bernardino Municipal Water Department

P.O. BOX 710

San Bernardino, California 92403

Dear Joe:

Enclosed is a short, preliminary sumary of some physical aspects of well TG-5A. This document has been prepared in the same format as that used to describe wells TG-1 and TG-2. We plan, of course, to integrate data from all the temperature gradient wells prior to recommending a location for the production well.

Please call if you have questions regarding this report or any other matter.

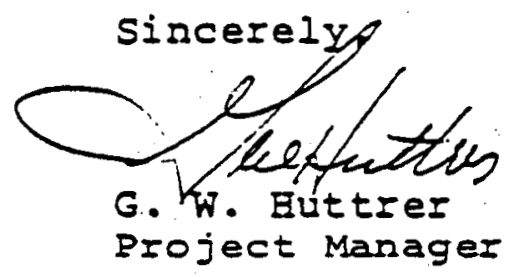

GWE : 5 jo

Enclosure

cc: E. F. WeIlbaum

D. A. Campbeli

C. F. Isselhardt

P. P. Parmentier

R. E. Yarter 
REPUBLIC GEOTHERMAL, INC.

\author{
$M E M O R A N D U M$
}

TO:

G. W. Euttrer

May 3, 1982

FROM: C. I. Isselharat C.F̆el.

SUBJECT: Iithologic Summary of Gradient Eole TG-5A

\title{
Iithology
}

The stratigraphic sequence encountered in the san Bernardino Municipal Water District (SBMWD) well TG-5A was determined by visual examination of the drill cuttings collected at 10-foot intervals.

A gamma ray log was run in this well in the open hole to further define and assist in the lithologic interpretation. The inthologic seguence encountered in this hole is essentially the same as that found in TG-1 and TG-2, composed predominantly of thin ( 2 to 10 feet) alternating beds of unconsolidated, medium- to very coarse-grained sands and pebbly sands, medium- to coarse-grained gravels, and sandy to silty clays. Although the lithologic descriptions (Appendix A) and the stratigraphic column (Figure 1 ) indicate some of the sands, gravels, and clays to be relatively thick units, the gamma ray log shows them to be thinner and intercaleted. This discrepancy may be attributed to the relatively large sampling interval and the probability that some samples have not been taken at the proper intervals.

As in the other wells drilled to date, the sediments in the Quaternary section (above 600 feet in $T G-5 A$ ) consist predominantly of unconsolidated sandy gravels, coarse pebbly sands, and silty clays with varying amounts of sand and gravel mixed in. The sands and gravels are generally multicolored (pink-white-gray) and are composed principally of granitic rock fragments and pink potassium feldspar crystals with minor dark lithic fragments. Bed thickness is highly variable, based on sample examination.

Below 600 feet the units are darker gray in appearance, and the percentage of dark lithic fragments of schist and gneiss are much 
Memorandum to G. W. Buttrer

May 3, 2982

Page 2

higher. This is interpreted to indicate that the well has penetrated the San Timoteo Formation. The sands appear to be more uniformiy sorted, and the clay content generaliy increases.

Several of the units are rich in pink feldspar and granitic rock fragments, making selection of the precise San Iimoteo Formation contact difficult. Several discrete sand units in the San rimoteo Formation appear to be 100 feet or more thick in the lower part of the hole, aithough the gamme ray log indicates the existence of numezous thin shale breaks.

Preliminazv Interpzetation and Comparison with Other Wells

As with TG-I and TG-2, all the units penetrated in TG-5A are sedimentary in nature. The lithology above 600 feet is interpreted to be Quaternary alluvial deposits, while the units below this depth are questionably San Timoteo Formation, a Tertiazy sedimentary unit of sands, clays, and conglomerates similar to the overlying alluvium.

The contact of the San Timoteo Fonmation is picked at almost the same depth as in TG-I and provides another datum point for future structural interpretation.

Logging of TG-5A

TG-5A was successfully logged with the gamm ray tool in the open hole interval 240 feet to 1,400 feet, providing a good guality log with excellent sand/shale discrimination. An SP-resistivity log was also Iun from 240 feet to 475 feet; unfortunately, the tool failed at that point, and we were unable to conduct any further logging opezations.

Preliminary Femperature Survey

On Monday, April 26, 1982, a preliminary temperature survey was run in TG-5A to a depth of 1,335 feet, four days after completion. Although the temperatures measured are not completely ecuilibrated, the shape of the profile (Figure 2) indicates the zone of convective flow and maximum temperature. It appears that this well did not peretzate the Loma Iinda fault which is estimated to be below 2,000 seet at this location.

The zone between 775 feet and 950 feet appears to be an aquifer containing water at $45^{\circ} \mathrm{C}$, based or the temperature profile. A tinal temperature survey will show the equilibrated temperatures but should not change the profile significantly. It is probable 
Memozandum to $G$. $W$. Huttrez

May 3, 1982

Page 3

that the hole is not very far away from the loma Iinda fault (horizontaliy) and that thermal waters have risen along the fallt and entered the 775-950 foot aquifer where they may be mixing with nonthermal ground waters that bring the temperatures down to $\pm 45^{\circ} \mathrm{C}$.

CFI : sjo

Attachments 


\section{APPENDIX A}

Iithologic Description of Hole TG-5A

\begin{tabular}{|c|c|c|}
\hline $0-10$ & feet & $\begin{array}{l}\text { Silty, sandy gravel - tan, with up to l" } \\
\text { diameter pebbles in fine, silty, micaceous sand } \\
\text { matrix, unconsolidated. }\end{array}$ \\
\hline $10-20$ & Eeet & $\begin{array}{l}\text { Unconsolidated sand-Eeldspathic, } \\
\text { coarse-grained, pink-tan, angular with mica. }\end{array}$ \\
\hline $20-40$ & feet & $\begin{array}{l}\text { Gravel - unconsolidated, } 1 / 8 "-1 / 4 " \text { diameter, } \\
\text { white, to dark gray, to pink, angular-subrounded } \\
\text { with mafic Iock fragments. }\end{array}$ \\
\hline $40-80$ & feet & $\begin{array}{l}\text { Silty clay - light brown, silty with los gravel } \\
\text { as above, micaceous. }\end{array}$ \\
\hline $80-100$ & Eeet & $\begin{array}{l}\text { Unconsolidated sand - multicolored pink-dark } \\
\text { gray, angular-subangular, very coarse sand to } \\
\text { fine gravel. } 15-208 \text { dark zock fragments. }\end{array}$ \\
\hline $100-170$ & feet & $\begin{array}{l}\text { Gravelly sand - as above, but gettins coerser to } \\
\text { medium size gravels. }\end{array}$ \\
\hline $170-190$ & feet & $\begin{array}{l}\text { Gravelly clay - medium gray clay, with 20-30s } \\
\text { sand and gravel as above. }\end{array}$ \\
\hline $190-200$ & feet & $\begin{array}{l}\text { Unconsolidated gravel - multicolored, } \\
\text { angular-subangular, with lo-i5z coazse } \\
\text { unconsolidated sand. }\end{array}$ \\
\hline $200-210$ & Eeet & $\begin{array}{l}\text { Unconsolidated gravel - with } 20-25 \text { s sand and } 5 f \\
\text { gray clay. }\end{array}$ \\
\hline $210-220$ & feet & $\begin{array}{l}\text { Wood fiber material - with some sand and clay, } \\
\text { possibly redwood. }\end{array}$ \\
\hline $220-280$ & Eeet & $\begin{array}{l}\text { Unconsolidated sandy gravel - as in 190-200 feet } \\
\text { with } 40 \text { f coarse sand. }\end{array}$ \\
\hline $280-290$ & feet & $\begin{array}{l}\text { Gravel - unconsolidated, poozly sorted, } \\
\text { multicolored, subround-angular, } 308 \text { pink } \\
\text { feldspar. }\end{array}$ \\
\hline $290-310$ & feet & $\begin{array}{l}\text { Sandy gravel - as above, with } 50 \text { o coarse to very } \\
\text { coazse sand with pink felcspar and granitic rock } \\
\text { Ezagments. }\end{array}$ \\
\hline $310-330$ & Eeet & Clay - tannish gray, with 10-15s sand and gravel \\
\hline $30-3$ & Ieet & Clay - as above, with 40 q coezse sand. \\
\hline
\end{tabular}




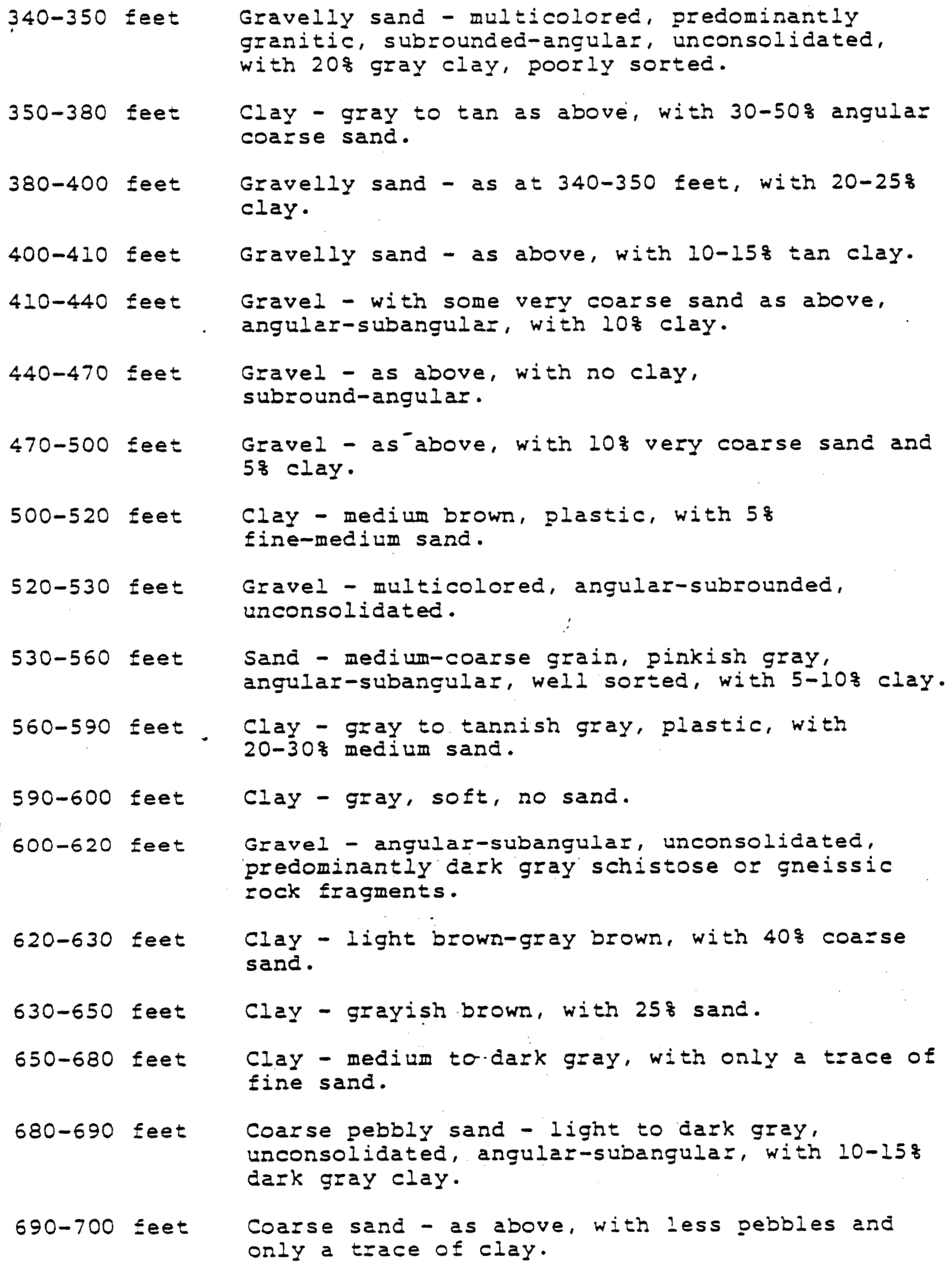




\begin{tabular}{|c|c|c|}
\hline $700-730$ & Eeet & $\begin{array}{l}\text { Clay - brownish gray, soft, with 5-108 medium } \\
\text { sand. }\end{array}$ \\
\hline $730-740$ & Eeet & $\begin{array}{l}\text { Coarse sand - unconsolidated, pink to dark gray, } \\
\text { angular-subangular, with some pebbles and } 5 \frac{8}{b} \\
\text { clay. }\end{array}$ \\
\hline $740-780$ & Eeet & Sand - medium-coarse grained as above, no clay. \\
\hline $780-790$ & Eeet & $\begin{array}{l}\text { Clayey sand - as above, with 40-508 brownish } \\
\text { gray clay. }\end{array}$ \\
\hline $790-810$ & Eeet & Clayey sand - as above, with 10-25\% clay. \\
\hline $810-820$ & feet & $\begin{array}{l}\text { Sand - medium to coarse grain, unconsolidated, } \\
\text { well sorted, with } 108 \text { clay. }\end{array}$ \\
\hline $820-850$ & Eeet & $\begin{array}{l}\text { Pebbly sand - as above, multicolored, generally } \\
\text { lighter colored with abundant pink feldspars, } \\
\text { not as well sorted. }\end{array}$ \\
\hline $850-940$ & Eeet & $\begin{array}{l}\text { Sand - moderately sorted sand, unconsolidated, } \\
\text { with 10-208 clay. }\end{array}$ \\
\hline $940-960$ & feet & Clay - light brown, with 10-15s fine-medium sand \\
\hline $960-1020$ & seet & $\begin{array}{l}\text { Sand - unconsolidated, coarse grained, } \\
\text { multicolored, pink-dark gray, pebbly, } \\
\text { angular-subangular, with 5-log clay. }\end{array}$ \\
\hline $20-1030$ & feet & Sand - as above, with $30-40 \%$ clay. \\
\hline $30-1040$ & feet & Sand - as above, with lof clay, nore pebbly. \\
\hline $040-1100$ & feet & $\begin{array}{l}\text { Sand - as above, medium-coarse grained, less } \\
\text { pebbly, trace to } 5 \frac{\text { clay. }}{}\end{array}$ \\
\hline $100-1300$ & feet & $\begin{array}{l}\text { Sand - fine-medium-coarse, moderately sorted as } \\
\text { above, no clay, some pebbles. }\end{array}$ \\
\hline $300-1340$ & Eeet & Sand - as above, with 5-108 clay. \\
\hline $0-1400$ & Eeet & Sand - as above, with 10-308 clay. \\
\hline & et & - bIownish gray, with 20-30z \\
\hline
\end{tabular}


FIGURE ?

SAN BERNARDINO MUNICIPAL WATER DISTRICT

TEMPERATURE GRADIENTIOBSERVATION WELL-TG \#5A

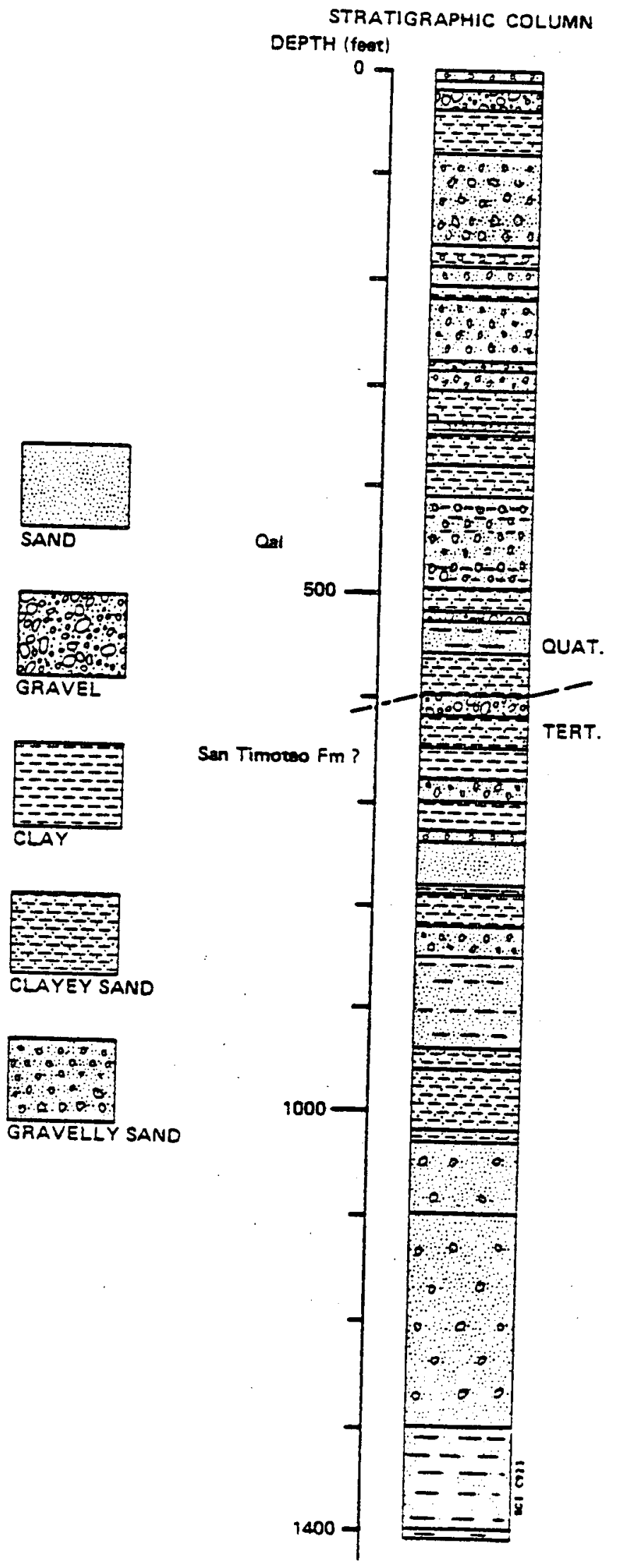


FIGURE 2

SAN BERNARDINO MUNICIPAL WATER DISTRICT

TEMPERATURE GRADIENTIOBSERVATION WELL-TG \# 5A

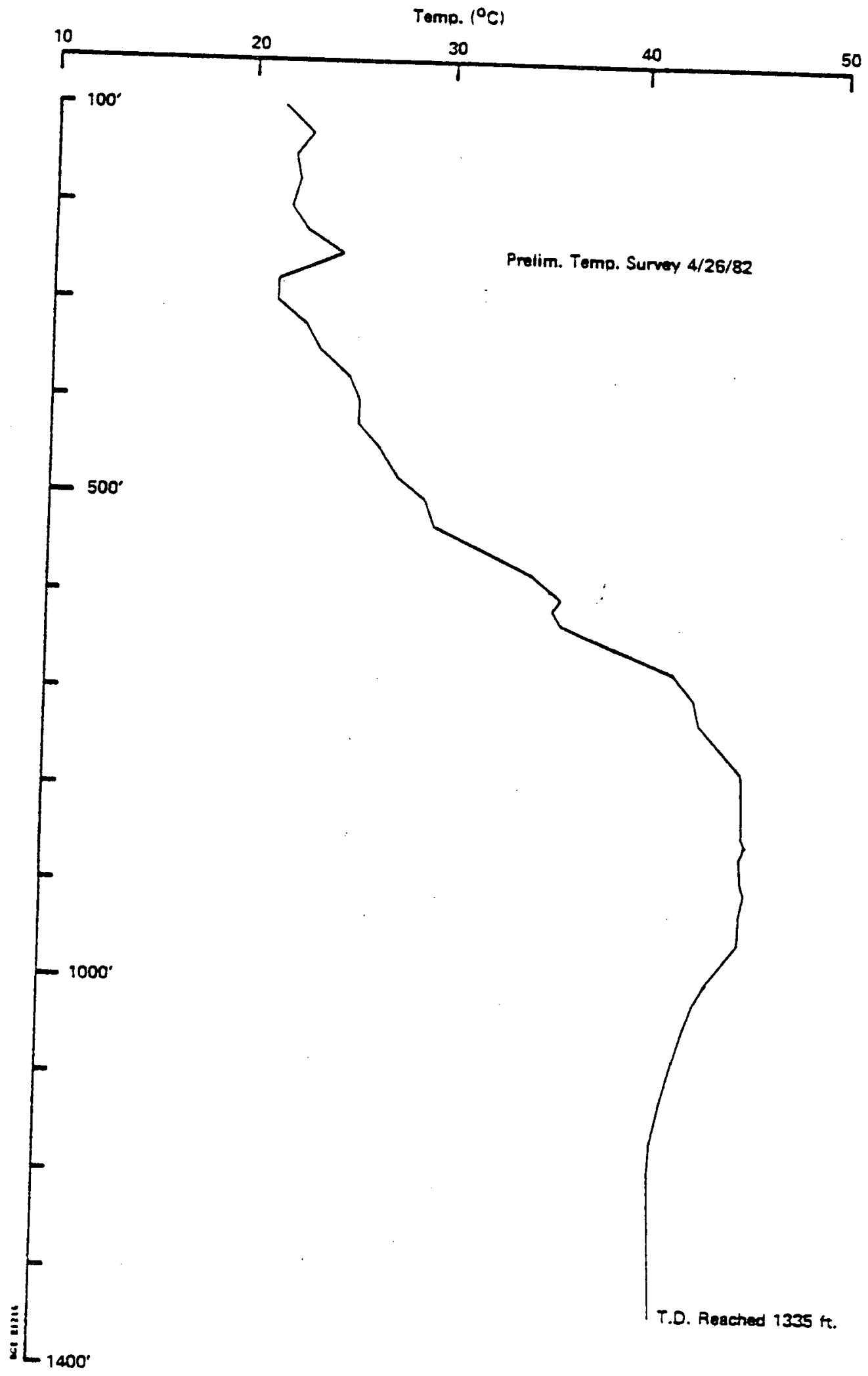


APPENDIX F 
TEMPERATURE $\left({ }^{\circ} \mathrm{C}\right)$

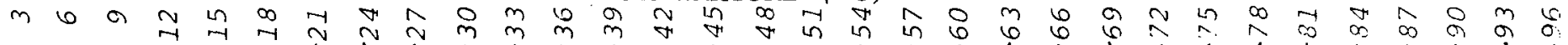

昰

a

贸

100.

200

\begin{tabular}{|l|l|l|}
\hline & & \\
\hline & & \\
\hline & & \\
\hline & & \\
\hline & & \\
\hline & & \\
\hline
\end{tabular}

\section{$+$}

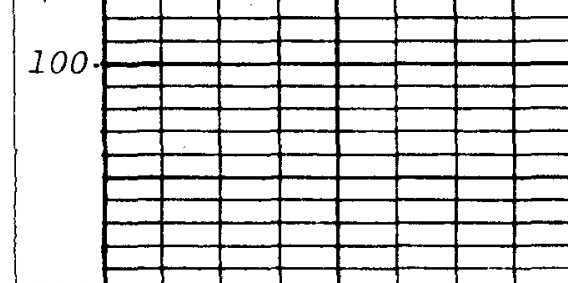

$E$

400

600

$1+20+2+1$
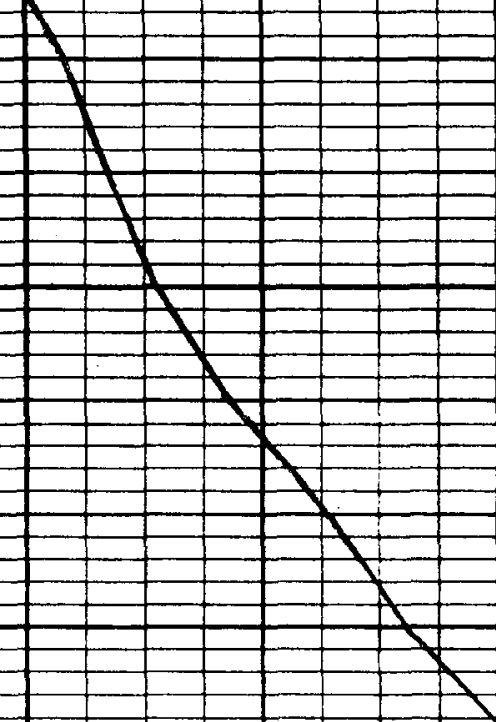

700

800

500

$-$

$+$

$-1$
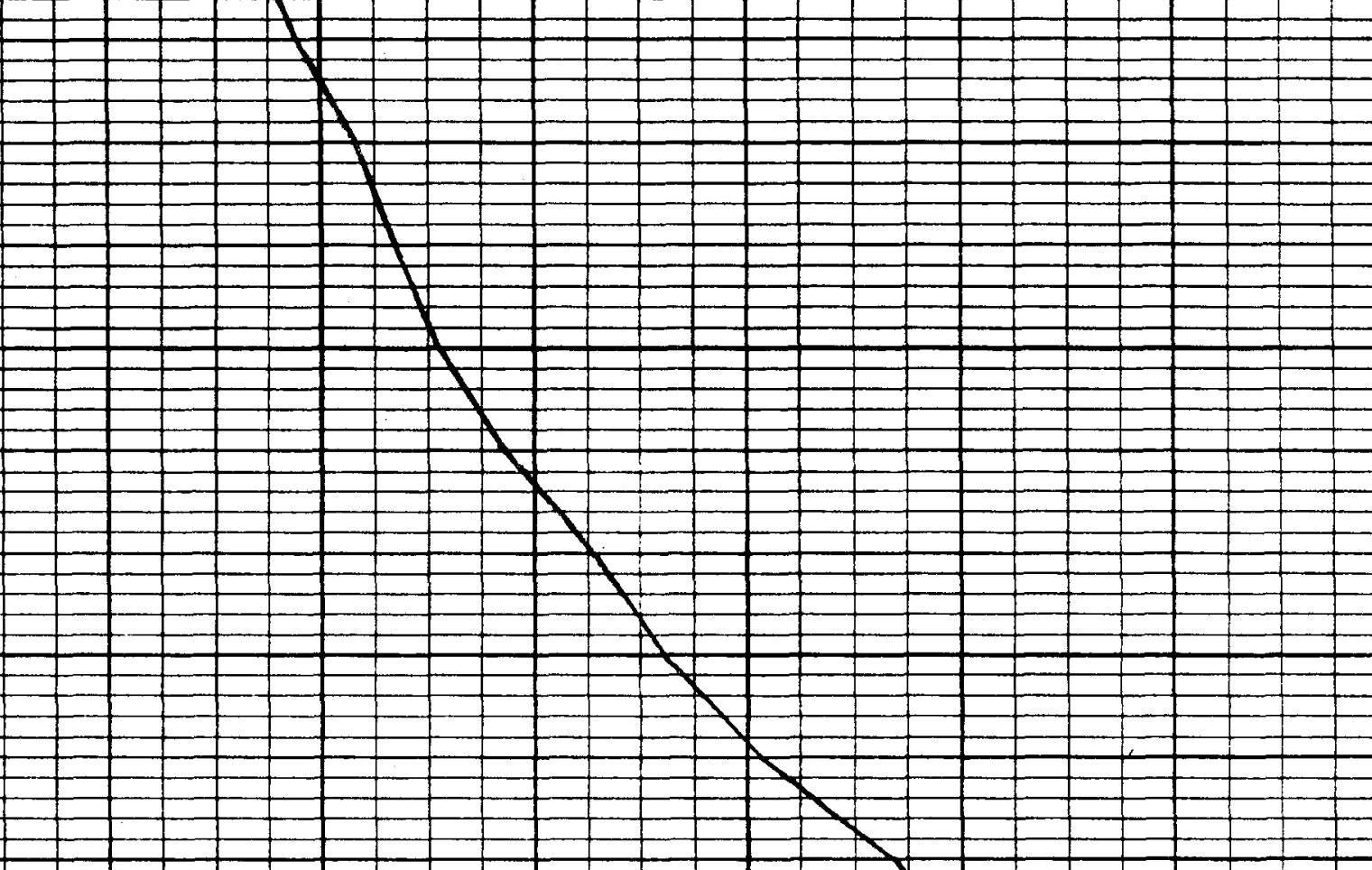

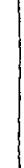

$-1-2+-1+2$

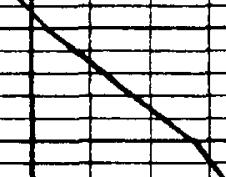

$70.33^{\circ}$
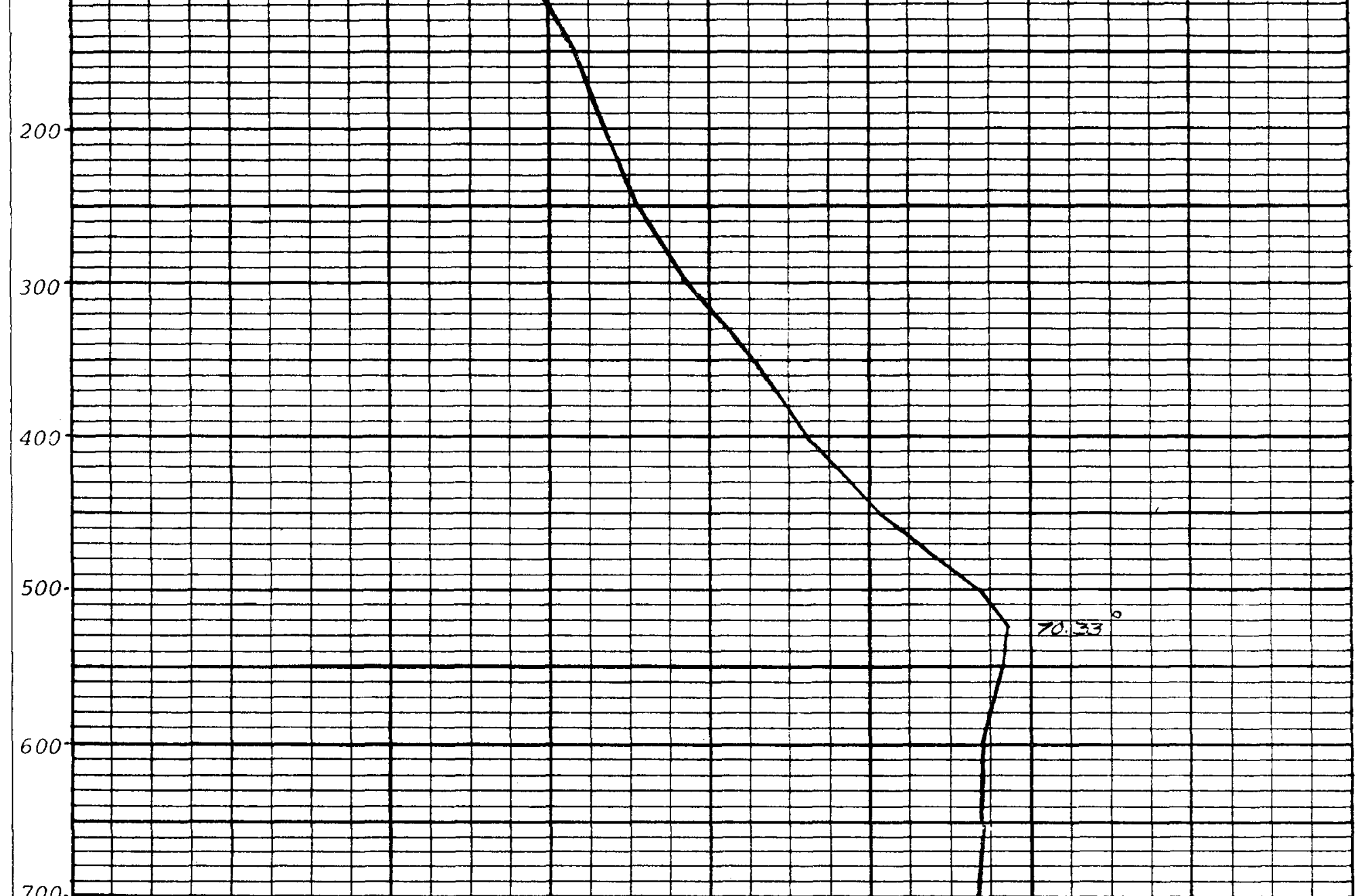

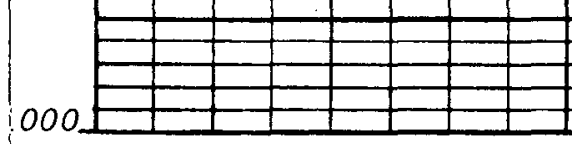
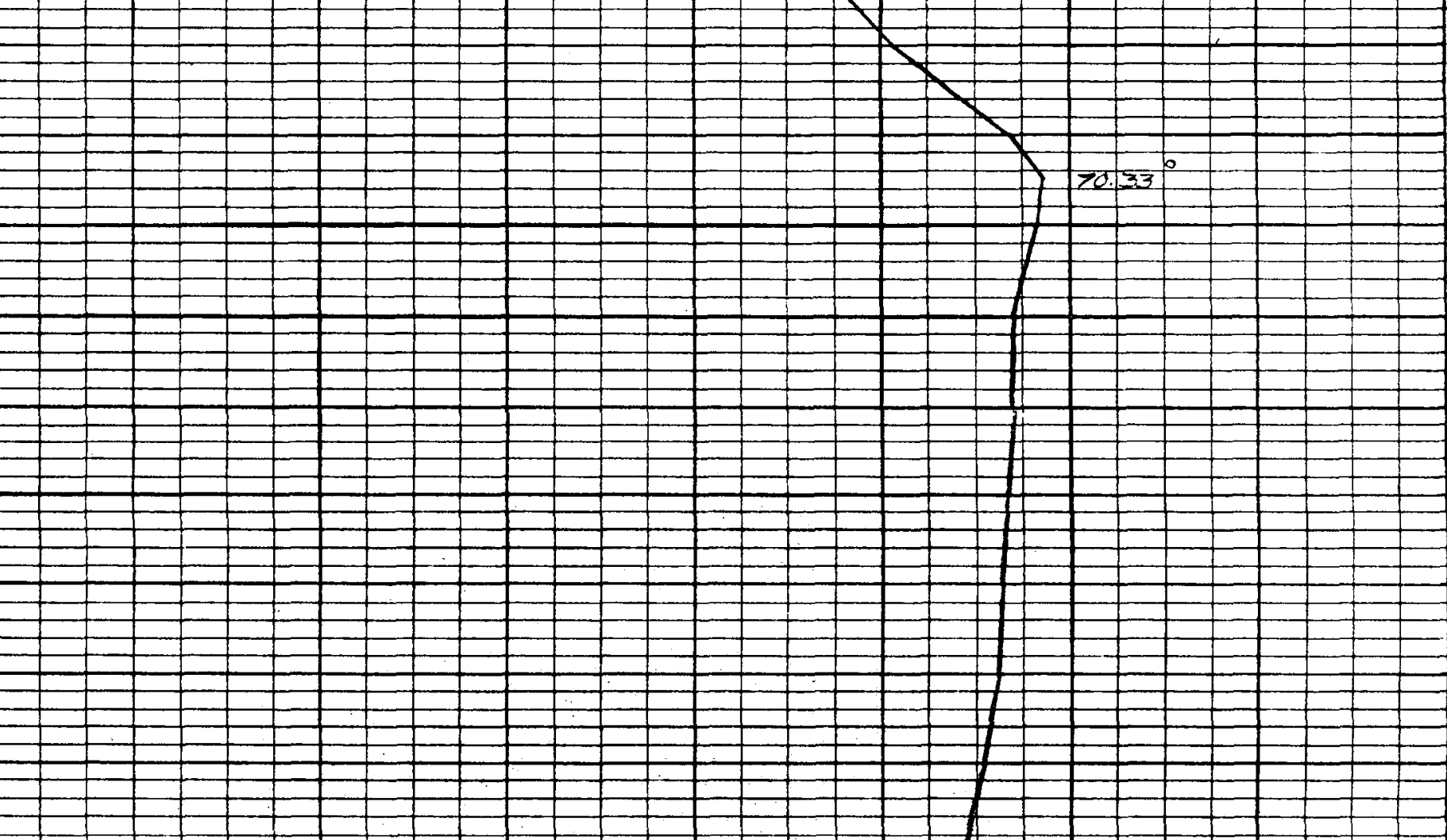
TEMPERATURE ( $\left.{ }^{\circ} \mathrm{C}\right)$

㲾

足

\begin{tabular}{ll|l|l|l|l|l|}
\hline & & & & & & \\
\hline & & & & & & \\
\hline
\end{tabular}

200

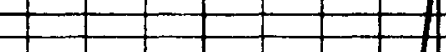

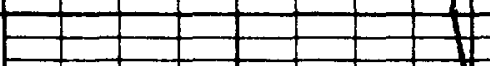

400

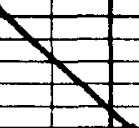

500

-
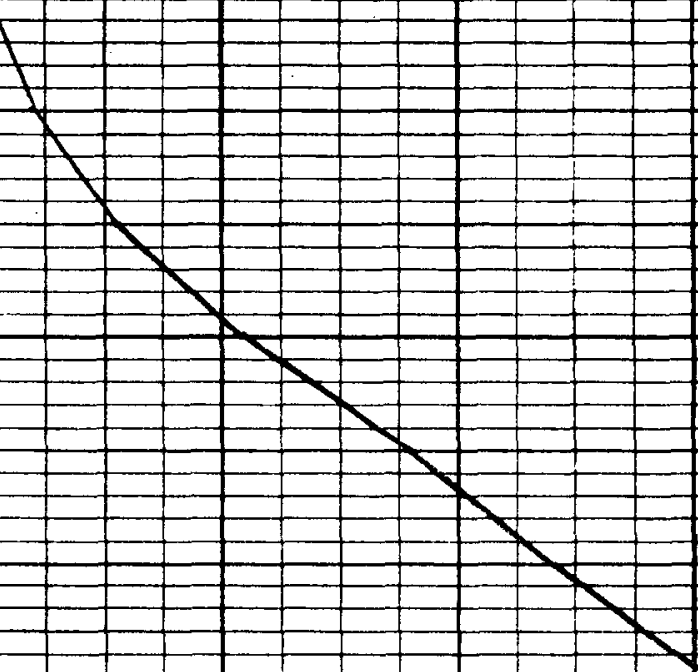

600

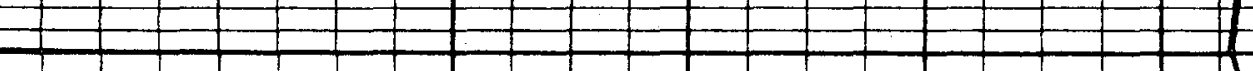

हस. II

800

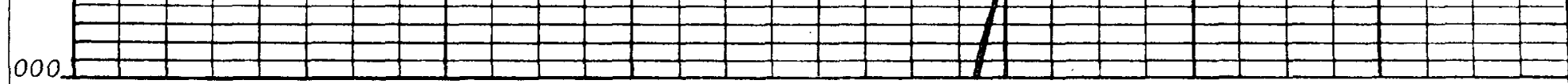

TEST DATE: AUGUST 23, 1983

TG NO. 2

TEMPERATURE GRADIENT LOG 